\title{
ARQUITETURA MBYÁ-GUARANI EM ÁREA DE MATA ATLÂNTICA: TIPOLOGIA ARQUITETÔNICA DA CASA DE XAXIM DO TEKOÁ NHÜU PORÃ - MAQUINÉ/RS
}

\author{
Letícia Thurmann Prudente ${ }^{1}$
}

A arquitetura dos povos indígenas no Brasil, a exemplo dos Mbyá-Guarani ${ }^{2}$, é uma das mais importantes fontes de referência de construções realmente sustentáveis em diferentes aspectos: ambiental, social, cultural e econômico. Este tema se torna especialmente relevante no atual contexto de globalização, cujos padrões de desenvolvimento estão centrados em modelos produtivos que privilegiam o consumo em grande escala, comprometendo a reserva de recursos naturais. A temática indígena na arquitetura, em conjunto com outras áreas, enfoques e olhares, contribui para a valorização e o diálogo sobre os ambientes e as comunidades autóctones que resistem aos modelos ocidentais de desenvolvimento.

Este artigo é fruto da dissertação de mestrado sobre a arquitetura autóctone do povo Mbyá-Guarani no estado do Rio Grande do Sul, desenvolvida em 2007, na PósGraduação em Engenharia Civil da Universidade Federal do Rio Grande do Sul, na Linha de Edificações e Comunidades Sustentáveis. Apresenta-se o estudo de caso sobre a tipologia arquitetônica da casa de xaxim, encontrada no Tekoá Nhüu Porã $\tilde{a}^{3}$, situada no município de Maquiné/ RS, região do litoral norte do Estado, cuja abundância de recursos naturais é existente devido à sua inserção em área de Mata Atlântica preservada.

O objetivo desse trabalho é apresentar as características dessa arquitetura, desenvolvida por essa comunidade indígena em um espaço socioambiental apropriado à reprodução de seu modo de construir culturalmente diferenciado. São descritos os elementos da tipologia arquitetônica, materiais, tecnologia e processo construtivo, a partir do contexto socioespacial e ambiental desse tekoá. A metodologia desenvolvida

\footnotetext{
${ }^{1}$ Universidade Federal do Rio Grande do Sul, Brasil.

${ }^{2}$ Os nomes dos povos indígenas são escritos no singular, assim como as palavras na língua Guarani, pois nesta língua não existe a forma plural (Felipim, 2001). Além disso, todas as palavras em Guarani são oxítonas e, para uma melhor leitura, estarão acentuadas e destacadas em itálico, com exceção dos nomes de grupo(s) ou subgrupo(s) e nomes próprios.

${ }^{3}$ Tekoá significa, na língua e na perspectiva Guarani, um espaço com paisagens e características específicas relacionadas a ambientes ideais onde a comunidade pode viver segundo seu "modo de ser" tekó ou rekó. $\mathrm{Na}$ literatura, tekoá é traduzido normalmente como “, cujo o termo está relacionado à imposição histórica de reservas indígenas fechadas (aldeamentos). Portanto, neste trabalho, assume-se o termo "comunidade" por entender ser mais apropriado à perspectiva Guarani.
} 
foi baseada no método etnográfico de levantamento de dados, através da pesquisa de campo realizada entre 2002 e 2006, de forma exploratória em 17 comunidades MbyáGuarani e específica na comunidade do estudo de caso. A sistematização dos dados de campo foi relacionada aos referenciais teóricos pertinentes, objetivando um diálogo entre a ótica dos saberes acadêmicos e autóctones.

Pretende-se contribuir para o reconhecimento do saber arquitetônico autóctone e contemporâneo dos Mbyá-Guarani no RS, os quais vêm buscando a atualização e a reprodução de seu modo de ser, através da expressão de sua cultura material desenvolvida nos distintos contextos socioespaciais existentes. De forma geral, o trabalho visa suprir a lacuna acadêmica existentes sobre essa temática e visa contribuir como suporte técnico para políticas públicas que busquem uma maior adequação social e cultural às especificidades desse povo indígena.

\section{O Território Mbyá-Guarani no RS}

O Território Mbyá-Guarani (Avy Mbyá Retã), reconhecido por eles com tal, compreende regiões dos estados nacionais do Brasil, Argentina, Paraguai e Uruguai extensa área que se conjuga ao Bioma Mata Atlântica. De acordo com Freitas (2004), esse território corresponde a uma biorregião em cujos ecossistemas buscam viver e reproduzir sua cultura diferenciada, priorizando áreas e espaços que apresentam espécies da fauna e flora associadas à criação divina. A noção de território e seus deslocamentos são diretamente relacionados aos mitos religiosos, principalmente a mito da "Terra sem Mal" (Yvy Marãe $y)^{4}$, no qual devem percorrer um percurso físico nesse amplo território, em um sentido anti-horário, partindo do interior do Paraguai, passando pelas regiões fronteiriças das Missões Jesuíticas, entre Argentina e Brasil, e chegando às faixas litorâneas brasileiras, desde o Rio Grande do Sul até o Espírito Santo. Na visão desse povo, esse território possui uma forma circular, cujo centro (Yvymbyté) se localiza entre o leste e o sul do Paraguai, circundado por diversas comunidades, denominadas tekoá.

\footnotetext{
${ }^{4}$ Lugar mitológico que integra diversos planos de realidade, além da realidade física do território propriamente dita.
} 
Tekoá é um conceito fundamental em relação à noção de território contemporâneo para os Mbyá-Guarani. Eles consideram tekoá como um espaço que vai além do físico, ideal para viver o seu modo de ser (tekó ou rekó) em comunidade, liderados pelo karaí (liderança espiritual). Para Ladeira e Matta (2004), tekoá são os espaços e paisagens que identificam as características e possibilidades deles atualizarem suas atividades sociais, políticas e religiosas, segundo seus costumes e leis. Assim, o Território Mbyá-Guarani é formado por diferentes tekoá articulados em redes, onde eles circulam constantemente, segundo a organização sociocultural dessa etnia. Conforme Freitas (2004), essa mobilidade gera o trânsito de pessoas e de recursos naturais, contribuindo para a conexão entre fragmentos de ecossistemas distantes e descontínuos. Nesse sentido, são essas redes que caracterizam a dinâmica de ocupação e de manejo do modo de ser desse povo, dentro do que consideram o seu território.

No Rio Grande do Sul, o Território Mbyá-Guarani consiste na rede dos tekoá existentes. Em 2005, quando foi realizada a pesquisa, havia ao todo 30 comunidades Mbyá-Guarani no Estado, de acordo com EMATER (2005), situadas em diferentes regiões do Estado e com distintas situações fundiárias. Desse total, 80\% correspondem a terras ou reservas indígenas e $20 \%$ a acampamentos provisórios. A figura 1 apresenta a localização das 30 comunidades em seus respectivos municípios e a delimitação da pesquisa, onde foi realizado o estudo de caso, no município de Maquiné, região nordeste do RS. 


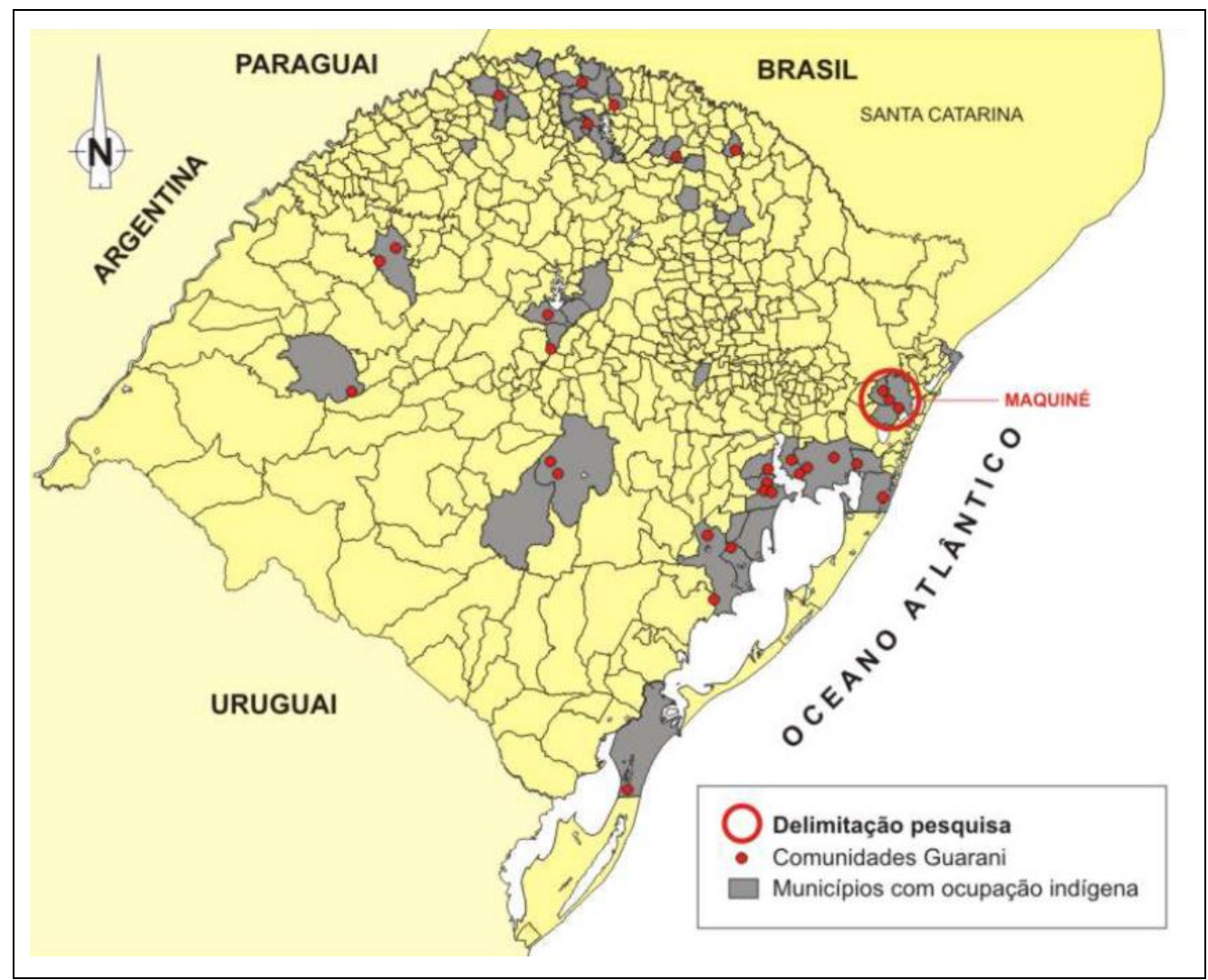

Figura 1: comunidades Guarani no Rio Grande do Sul.

Fonte: modificação sobre imagem de CEPI (2006); Ladeira e Matta (2004).

O estudo de caso da pesquisa, o Tekoá Nhüu Porã consiste em uma das mais importantes terras indígenas do Estado, por ser a maior, com 2.266,52 hectares (homologada 2001), e estar localizada distante de áreas urbanas, abrangendo uma ampla diversidade de recursos naturais, típicos do Bioma Mata Atlântica. Além disso, essa comunidade foi uma das poucas que não aceitou receber recursos governamentais para a construção de habitações, o que fez com que suas casas sejam todas construídas com sua arquitetura autóctone. Nessa comunidade, a "casa tradicional”, como os MbyáGuarani a denominam, se caracteriza como uma tipologia arquitetônica específica desse local, na qual o xaxim (Samambaiaçu) é utilizado com material construtivo, diferenciada das demais comunidades do Estado. 
Os Mbyá-Guarani somam, no RS, aproximadamente 1.500 a 2.000 pessoas número que varia, devido às especificidades da itinerância tradicional dentro do Território Guarani (EMATER, 2005). Cabe mencionar que, além desse povo, há no RS os Nhandevá-Guarani ${ }^{5}$ e os Kaigang. Tais comunidades se encontram, atualmente, apoiadas por instituições federais, como Ministério Público, FUNAI, Fundação Nacional de Saúde (FUNASA) e Universidade Federal do Rio Grande do Sul (UFRGS), bem como por instituições locais importantes, como a Associação Rio-grandense de Empreendimentos de Assistência Técnica e Extensão Rural (EMATER- RS) e o Conselho Estadual dos Povos Indígenas (CEPI). Destaca-se o CEPI por ser uma instância governamental que reúne representantes das secretarias estaduais e dos povos indígenas existentes no Estado, Guarani e Kaigang, promovendo a interface política entre o Estado e as organizações indígenas. No caso dos Mbyá-Guarani, são organizados sob uma liderança regional denominada Cacique-Geral (Mburuvixá Tenondé), exercida por José Cirilo Morinico ${ }^{6}$. Nesse contexto político, tornou-se possível a elaboração de políticas públicas indigenistas mais adequadas às suas especificidades culturais.

A arquitetura autóctone Mbyá-Guarani no RS foi evidenciada a partir de políticas públicas diferenciadas, associadas a trabalhos já desenvolvidos pela PósGraduação em Antropologia Social da Universidade Federal do Rio Grande do Sul (UFRGS). Porém, não foram inicialmente políticas voltadas à Habitação e sim à Saúde, através de um trabalho de extensão rural e assistência técnica desenvolvido por antropólogos da Associação Rio-grandense de Empreendimentos de Assistência Técnica e Extensão Rural (EMATER) e do RS Rural ${ }^{7}$, entre 2004 e 2006. Nesse período, houve a participação indígena nas definições sobre recursos e demandas, direcionados à construção de casas tradicionais, um processo que visava trabalhar a saúde indígena, principalmente problemas relacionados ao alcoolismo.

\footnotetext{
${ }^{5}$ Os Nhandevá-Guarani, junto com os Mbyá-Guarani e os Kaiová-Guarani formam as três parcialidades linguísticas e cultural dos Guarani, mantendo algumas diferenças de dialeto, costumes e rituais, bem como a forma de ocupação do território (Felipim, 2003).

${ }^{6}$ Essa liderança veio a ser um dos mais importantes interlocutores culturais nos diálogos políticos e nas pesquisas sobre a arquitetura autóctone dos Mbyá-guarani, inclusive para esse trabalho. Suas informações foram coletadas através de entrevistas semiestruturadas e outros instrumentos metodológicos.

${ }^{7}$ RS Rural é fruto de um contrato entre o estado do Rio Grande do Sul, através da Secretaria de Agricultura e Abastecimento (SAA) e o Banco Mundial (BIRD), desenvolvido de 1997 a 2004 (Soares, 2007).
} 
Esse processo culminou na construção de casas consideradas pelos MbyáGuarani como "casas tradicionais", as quais tinham determinadas características de materiais e técnicas específicas ${ }^{8}$, diferenciadas das casas que estavam recebendo do Governo Estadual. As casas tradicionais eram as casas de reza (opy), nas quais foram trabalhadas e resolvidas as questões de saúde, através das lideranças espirituais (karaî), justamente as pessoas que costumavam ter problemas de alcoolismo. Assim, foram construídas e/ou reformadas casas de rezas na maioria das comunidades do RS, passando a representar, a partir de então, uma tipologia arquitetônica culturalmente diferenciada desse povo. Foi um processo de resultado positivo, tanto para o objetivo do trabalho com a saúde quanto para esse reconhecimento de arquitetura autóctone. Além disso, esse povo passou a estar mais aberto ao diálogo com os pesquisadores da UFRGS, permitindo o desenvolvimento desse e de outros trabalhos na área de construções sustentáveis.

\section{As construções existentes nos tekoá}

As construções existentes nos tekoá do RS consistem em suas casas tradicionais, construídas conforme os preceitos da arquitetura autóctone dos Mbyá-Guarani, e edificações provenientes de intervenções externas dos distintos órgãos que atuam junto às comunidades.

A reprodução da casa tradicional, entre outros processos, consiste em uma das bases da sustentabilidade para esse povo. A sustentabilidade para eles é ter uma casa de reza no tekoá e essa casa só pode ser utilizada como tal se for uma casa tradicional. O fato de terem recebido recursos para a construção e reforma de casas de reza, através da assistência técnica da EMATER e RS Rural, acabou reforçando a questão da religiosidade para eles, além de poderem mostrar como era a sua arquitetura autóctone. A partir desse processo, puderam contar com um espaço físico adequado ao seu modo de ser e a sua cosmologia, bem como a tipologia arquitetônica da casa de reza passou a ser a da casa tradicional dos Mbyá-Guarani no RS, como parte fundamental no contexto de um tekoá ideal para eles atualmente.

\footnotetext{
8 "Casa tradicional" foi o termo utilizado pelos interlocutores Mbyá para se referirem a suas tecnologias, materiais, conceitos e conhecimentos construtivos; em oposição a outras formas de habitação advindas de projetos ou políticas públicas (Casa do Governo).
} 
Em relação ao acesso aos materiais apropriados para construção dessa casa, dentro do possível, os Mbyá-Guarani buscam construir casas tradicionais em suas áreas, para que suas comunidades venham a se constituírem como um tekoá. Há pelo menos uma casa tradicional em cada comunidade do RS, a qual é a casa de reza (opy) do tekoá. Algumas comunidades, localizadas em ambientes com disponibilidade de recursos naturais, têm somente casas tradicionais, como o caso do Tekoá Pindoty, no município de Camaquã, e do Tekoá Nhüu Porã (estudo de caso desse trabalho). Diferentemente das demais comunidades do Estado, essas duas negam os recursos externos a sua cultura, principalmente em relação às construções provenientes de políticas públicas habitacionais. A figura 2 mostra algumas casas tradicionais existentes nesses dois tekoá.



Figura 2: Casas tradicionais no Tekoá Pindoty e no Tekoá Nhüu Porã. Fotos: Nauira Zanin (2006) e Letícia Prudente (2006).

Devido à escassez de matérias primas de origem vegetal, que são prioritárias nas construções das casas tradicionais, a maioria das comunidades no RS vem aceitando a intervenção da sociedade não-indígena em suas áreas. Em 2005, conforme a EMATER, o déficit habitacional nas comunidades indígenas no RS era de 239 casas e, por isso, a Secretaria Estadual de Habitação (SEHAB) desenvolveu uma tipologia arquitetônica residencial que buscou responder a algumas das características construtivas e necessidades de uso dos indígenas no Estado, denominada como "casa do índio". Para os Mbyá-Guarani essa tipologia ficou denominada como "casa do governo". 
A tipologia da "casa do governo" utiliza a madeira como material construtivo estrutural e de vedação, por ser um material natural, ao invés da alvenaria. Além disso, a cobertura é de telha cerâmica e tem uma área aberta na frente que pode ser utilizada para fazer o fogo de chão, tradicional da cultura indígena. Entretanto, conforme Zanin (2006), tanto esses materiais quanto o processo construtivo não correspondem à cultura construtiva desse povo, o que gerou problemas de conservação da construção. Alguns aspectos de conservação não puderam ser resolvidos por eles mesmos e, assim, acabaram abandonando algumas casas. A figura 3 mostra a tipologia da "casa do governo", construída em série, lado a lado, no Tekoá Anhetenguá, situado na capital.

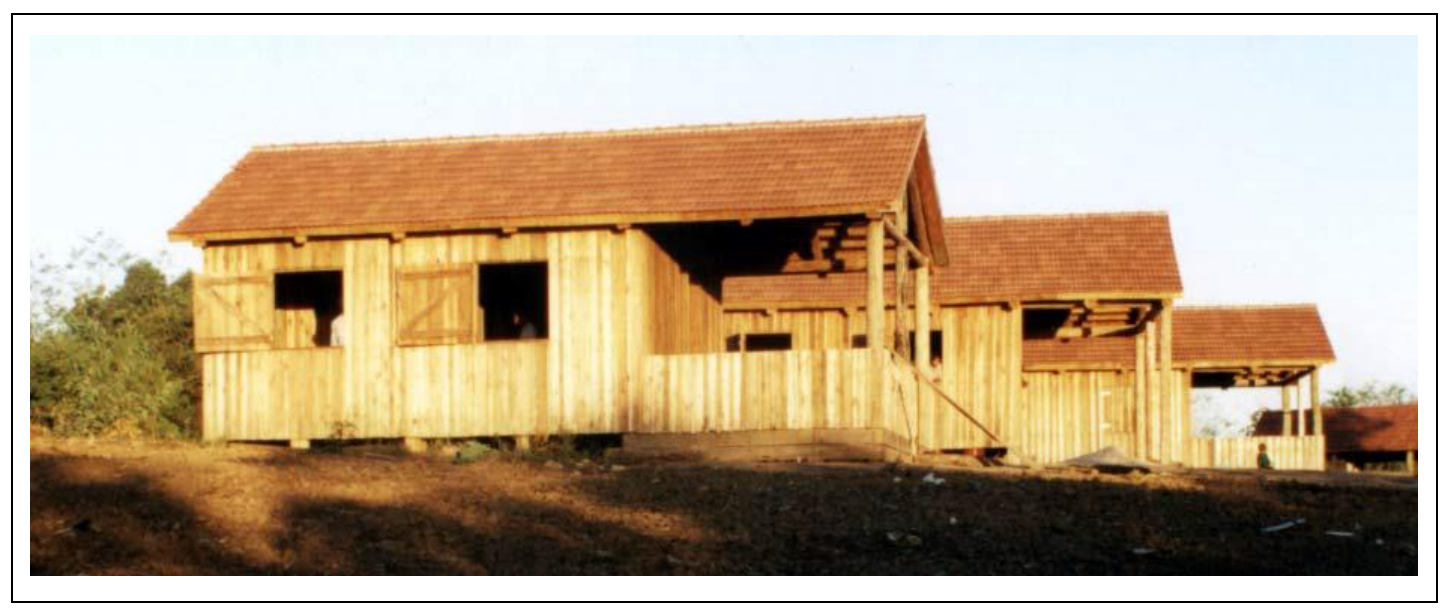

Figura 3: Tipologia da "casa do governo", desenvolvida pela SEHAB.

Foto: Mariana Soares (ZANIN, 2006).

Zanin (2006) destaca que a casa do governo acabou proporcionando mudanças no comportamento dos Mbyá-Guarani, como a indução a novas necessidades que, até então, não existiam. Uma dessas necessidades é o uso da energia elétrica, também proveniente de intervenções externas, principalmente através do através do Programa Luz para Todos do Governo Federal ${ }^{9}$, que propiciou a instalação de redes. Desta forma, muitas comunidades vivem entre as duas culturas (indígena e não-indígena), usando tanto casas tradicionais quanto "casas do governo", o que vem gerando alguns conflitos, sobretudo entre os mais jovens que se distanciam das tradições. Essa questão é apontada justamente pelos mais velhos que se esforçam para tentar fortalecer a cultura material de

\footnotetext{
${ }^{9}$ Programa do Ministério de Minas e Energia, iniciado em 2003, que instalou gratuitamente redes de energia elétrica em diversas comunidades no País, a fim de "acabar" com a exclusão elétrica.
} 
seu povo. Os mais velhos sofrem por não se adaptarem às construções consideradas não tradicionais ou pelo fato inconveniente de estarem entre as duas culturas.

Além disso, a autora supracitada também aponta que eles acabam utilizando a “casa do governo" para as atividades e os elementos da cultura não-indígena, como o uso da televisão, fogão ou armários, enquanto a casa tradicional é utilizada para seus costumes, como acender o fogo em seu interior. Essa dualidade ocorre somente quando conseguem acessar alguns recursos naturais para construir uma casa tradicional e, assim, acabam tendo duas casas. A figura 4 apresenta a casa do governo ao lado de casas tradicionais nos Tekoá Ka'a Mirindy, no município de Camaquã, e no Tekoá Koenjú, em São Miguel das Missões.

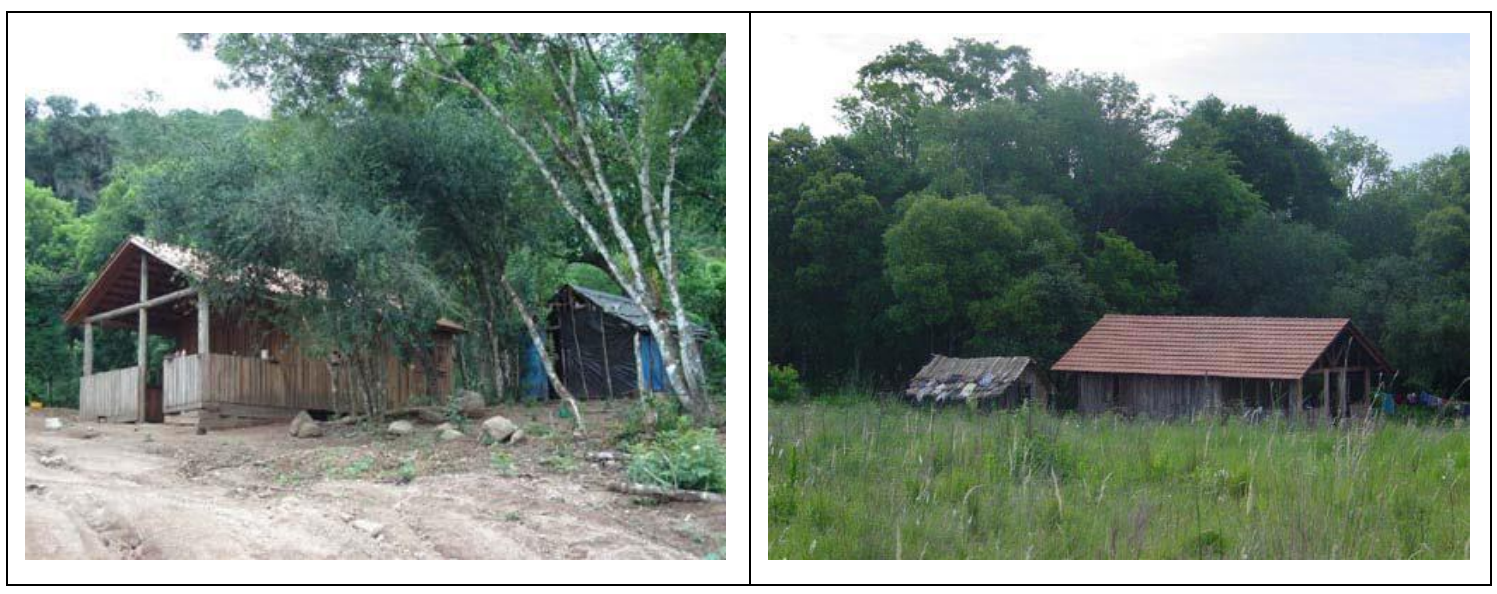

Figura 4: Casa do governo do RS e casa tradicional Mbyá-Guarani.

Fotos: Letícia Prudente (2006) e Nauira Zanin (2006).

Comparativamente, há uma grande diferença nas dimensões entre ambas as tipologias, da casa do governo e da casa tradicional Mbyá-Guarani, construída ao lado, como mostra a figura acima. A primeira tem o dobro ou mais das dimensões da segunda. Além disso, em relação aos materiais construtivos, alguns utilizados na "casa tradicional" são provisórios, como o uso da lona plástica - material encontrado com mais facilidade nas cidades próximas. Esse material sintético é utilizado como vedação lateral e também como cobertura até o momento que eles conseguem acessar recursos naturais utilizados tradicionalmente. $\mathrm{O}$ uso de lonas plásticas é frequente, principalmente em de acampamentos de beira de estrada, mas as dimensões e as técnicas construtivas seguem a tipologia arquitetônica da casa tradicional. A figura 5 mostra duas casas tradicionais, uma no acampamento do Petim, no município de 
Guaíba, e outra no Tekoá Anhetenguá, na capital - ambas construídas com a técnica de pau-a-pique (explicada posteriormente).

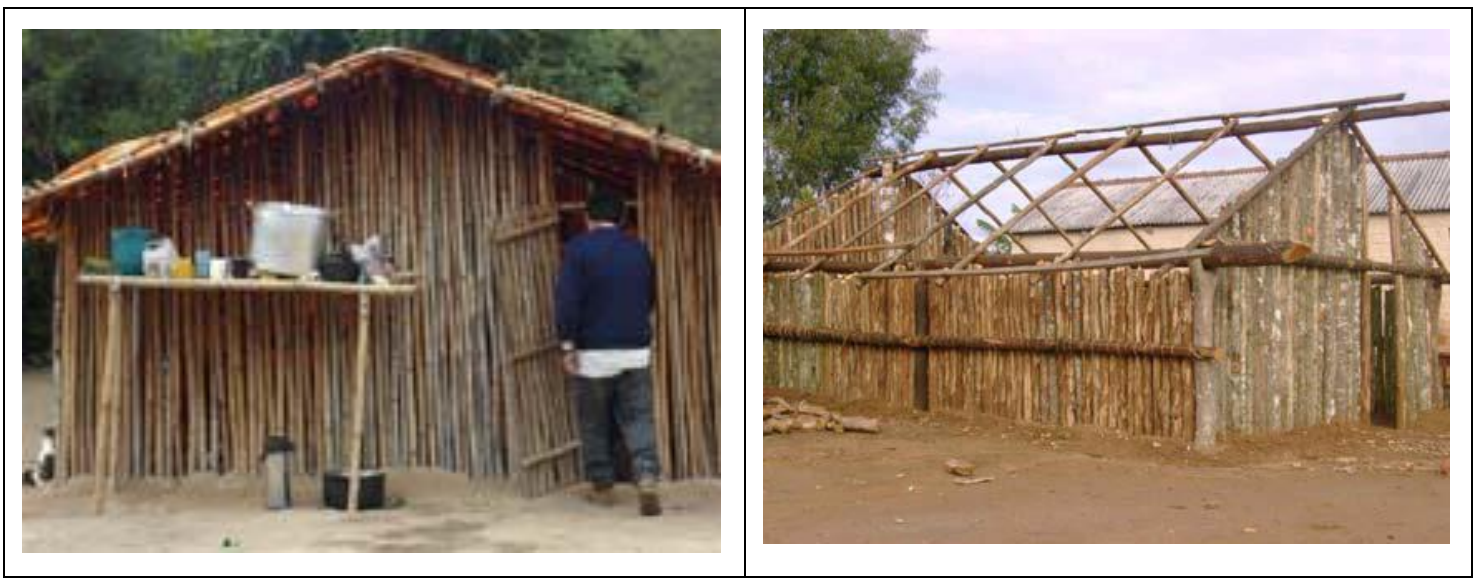

Figura 5: casas tradicionais no acampamento e no tekoá.

Fotos: Letícia Prudente (2007) e Jefferson Pinheiro (2007).

Outra tipologia arquitetônica proveniente de intervenções externas são as construções realizadas FUNASA para serem postos de saúde. São construções completamente distantes da cultura material tradicional dos Mbyá-Guarani, pois são construções padrões utilizadas em diferentes comunidades no País, indígena ou nãoindígena, que tem como característica o uso da alvenaria como material construtivo, entre outros materiais industrializados, inclusive materiais de alto custo, como o tijolo de vidro. No RS, foi construído praticamente um posto de saúde em cada tekoá do Estado, construção que vêm impactando não só culturalmente, mas também ambientalmente as áreas indígenas. As obras para a construção dos postos geraram grandes movimentações de terra que modificaram a topografia e a paisagem das comunidades inseridas em áreas de preservação. A figura 6 mostra duas dessas construções, uma no Tekoá Ka'a Miridy, no município do Caraá, e outra no Tekoá Anhetenguá, na capital. 


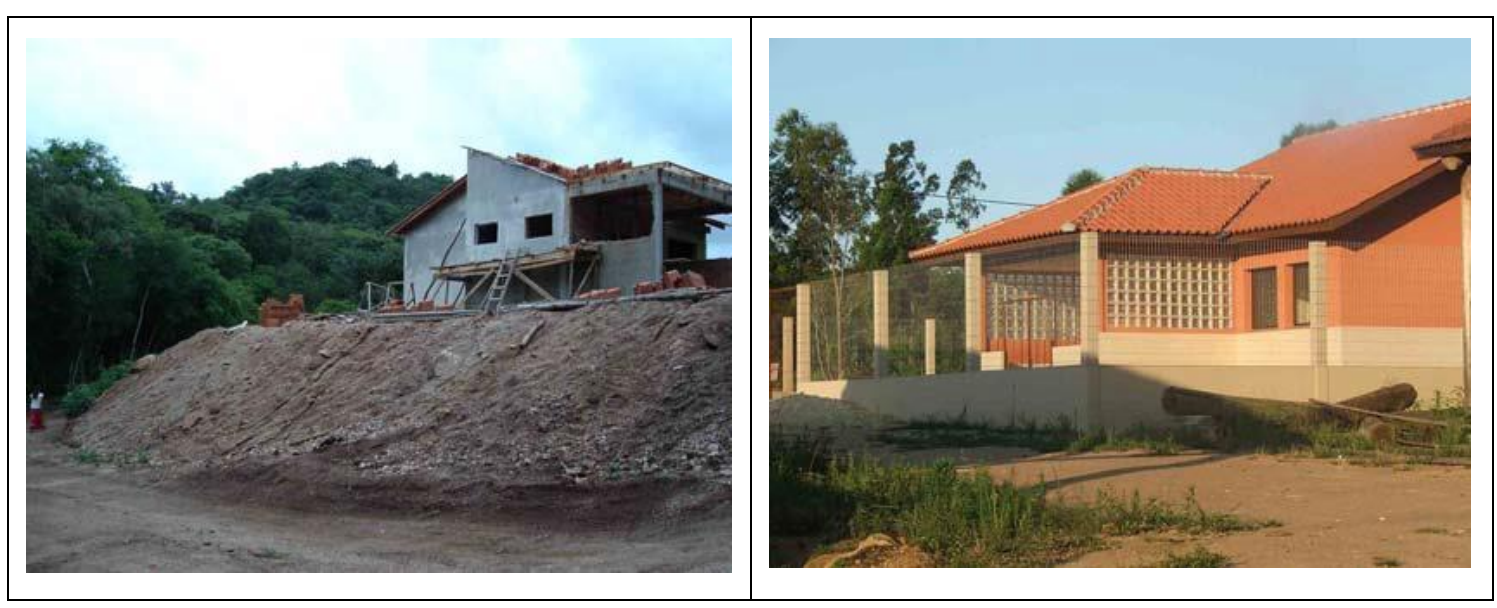

Figura 6: Casas tradicionais no acampamento e no tekoá.

Fotos: Letícia Prudente (2007) e Jefferson Pinheiro (2007).

Outra construção que cabe registrar ainda, mas que teve um impacto positivo, foi uma casa desenvolvida pelos alunos da Faculdade de Arquitetura da UFRGS, cujo projeto buscou um maior diálogo intercultural e teve um resultado razoável por inserir elementos construtivos tradicionais dos Mbyá-Guarani. Essa casa foi construída pelo governo do Estado no Tekoá Anhetenguá, na capital, e foi denominado por eles de "casa tatu". O objetivo dessa casa era ser uma unidade habitacional, porém a comunidade acabou utilizando-a como um centro cultural. A tipologia arquitetônica da "casa tatu" consiste em estrutura de madeira e o uso da palha (capim santa-fé) como cobertura e vedação lateral. A palha é um dos materiais naturais, tradicionalmente utilizado por eles. Um dos aspectos mais importantes dessa casa é fato de ter sido prevista a possibilidade de se fazer fogo de chão em seu interior, devido à possibilidade de ventilação na cobertura. A figura 7 apresenta uma imagem externa e interna dessa casa.



Figura 7: “Casa tatu” no Tekoá Anhetenguá.

Fotos: Letícia Prudente (2007). 
Algumas das tipologias arquitetônicas construídas por intervenções externas à cultura Mbyá-Guarani no RS têm servido para uma reflexão sobre como dialogar, respeitar e/ou assessorar, se for o caso, esse povo em relação à produção de sua cultura material no contexto atual. Cabe ressaltar que a casa do governo da SEHAB e a casa tatu da UFRGS contribuíram para o fortalecimento cultural e o reconhecimento de um saber autóctone construtivo, assim como auxiliaram a pensar em possibilidades mais sustentáveis ambientalmente e culturalmente nas áreas indígenas, principalmente porque buscaram o diálogo com as próprias comunidades. Porém, o tema da arquitetura autóctone indígenas ainda deve ser aprimorado. Assim, a descrição da tipologia arquitetônica desenvolvida no Tekoá Nhüu Porã vem a contribuir com algumas informações sobre a cultura material construtiva desse povo.

\section{A arquitetura do Tekoá Nhüu Porã}

Tekoá Nhüu Porã significa Aldeia do Campo Bonito em Guarani, ou Aldeia do Campo Molhado, devido ao alto índice pluviométrico e às grandes áreas alagadiças da região. Legalmente é denominada Terra Indígena (TI) Barra do Ouro, por ser o nome de um dos distritos rurais do município de Maquiné, por onde chegaram os primeiros Mbyá-Guarani na região. Foi homologada pela União como tal em 2001, com 2.266,52 hectares, situada nos limites entre os municípios de Maquiné, Caraá e Riozinho - litoral norte do Estado, mais especificamente, na Serra da Boa Vista, no alto do Vale do Maquiné, em uma altitude em torno de 900m. Nesse vale, cabe registrar que há alguns acampamentos Mbyá-Guarani que são parte do território da rede sociopolítica desse tekoá.

O município de Maquiné tem uma importância para esse povo por ter sido o local onde as primeiras famílias chegaram ao vale e se instalaram em sua área baixa. Segundo Vietta (1992), essas famílias vieram da Missiones, na Argentina, em torno de 1970. A atual liderança espiritual (karaî) do Tekoá Nhüu Porã foi um dos que vieram e lembram dessa trajetória. Essa pessoa costuma registrar a cultura Mbyá-Guarani desse tekoá em desenhos, os quais mostram a importância das relações entre a comunidade, situada na parte alta do vale, e o centro do município de Maquiné, situado na parte baixa, onde estão seus acampamentos. A figura 8 mostra alguns aspectos sobre essa relação, bem como sobre a abundância de recursos naturais existentes e utilizados em suas casas tradicionais. 




Figura 8: Representação do tekoá como casa tradicional, por José Verá Rodrigues.

Fonte: ASSECAN, 2007.

Nos dois desenhos, a casa tradicional é o centro do desenho e representa o próprio tekoá, em conjunto com os elementos simbólicos da cultura material MbyáGuarani. No primeiro, a casa (o tekoá), situado no município de Maquiné, está ligada por caminhos que levam ao "município" (área baixa do vale, onde se situa a cidade) e aos municípios de Riozinho e de Caraá, onde se localizam o Tekoá Itapoty e o Tekoá Ka'aguy Pau, respectivamente. Outra questão pontuada é a abundância de águas, característica da região, representada por distintas linhas: córregos, banhados e rios. Em relação à casa ao centro, há sobre ela a representação de uma importante espécie arbórea utilizada como estrutura principal da casa: o cedro, que, na mitologia desse povo, traz proteção espiritual. Em ambos os lados da casa estão também representadas outras duas espécies vegetais: a araucária, utilizada como alimento (pinhão), e o xaxim, utilizado como material construtivo. Essas três espécies vegetais são nativas da região de Mata Atlântica e existem em abundância nessa região. No segundo desenho, pode-se perceber melhor que a casa é revestida de xaxim, utilizado como material de vedação (parede), o qual está também representado em ambos os lados da casa. Essa casa (tekoá) está sob a proteção do sol (Nhamandú), que é a principal divindade para eles, representando a paisagem de um lugar ideal para o seu modo de ser.

Cabe ressaltar que a casa de xaxim encontrada no Tekoá Nhüu Porã é uma tipologia arquitetônica única dentre os demais tekoá do Estado. Os Mbyá-Guarani utilizaram o xaxim - espécie de samambaia - como elemento de vedação lateral (paredes), diferentemente das demais comunidades que constroem as casas normalmente com paredes de toras cobertas com barro (técnica de pau-a-pique com cobertura de taipa de mão). Além disso, nesse tekoá, a cobertura é feita com o uso da 
taquara batida, enquanto nos demais tekoá é feita com o uso da palha. A figura 9 mostra a tipologia arquitetônica da casa de xaxim no Tekoá Nhüu Porã e da casa de barro no Tekoá Anhetenguá, (capital).

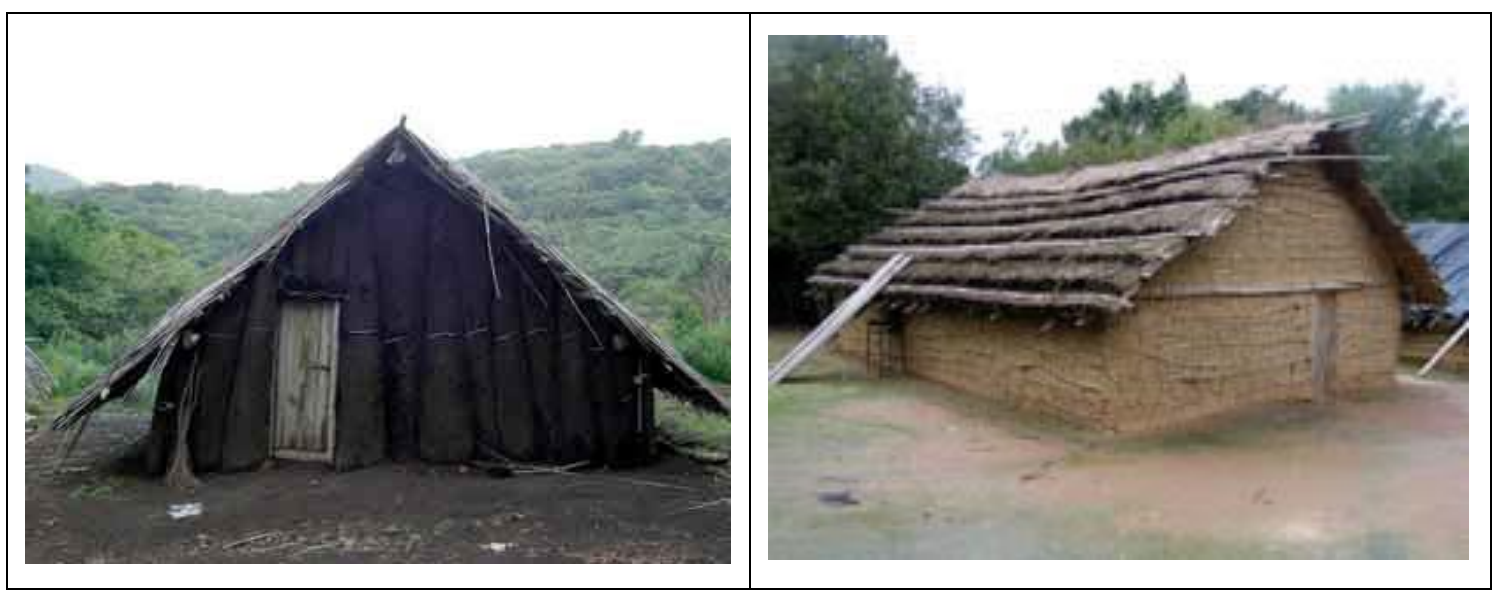

Figura 9: Casas de reza do Tekoá Nhüu Porã e do Tekoá Anhetenguá. Fotos: Letícia Prudente (2006) e Vivian Ecker (2007).

Ambas as tipologias são consideradas por eles como casas tradicionais. Cabe mencionar que a casa em Guarani se denomina oga, ou oó. Historicamente, segundo Weimer (2005), antes da colonização, essa denominação se referia ao espaço interno que cada família nuclear tinha dentro de uma "casa grande" dos Tupi-Gurani. Essa casa grande era denominada de maloca ou maioca. Esse autor explica que as dimensões dessa casa grande variavam de acordo com o número de famílias nucleares existentes em cada comunidade, as quais tinham um espaço interno delimitado por pilares e sem divisórias, onde faziam um fogo próprio. De acordo com Rapoport (1972), cada comunidade podia reunir dezenas ou centenas de pessoas, ao passo que hoje cada família ocupava um espaço interno delimitado por pilares, sem divisórias e com um fogo próprio. Portanto, segundo um olhar histórico, a trajetória das casas tradicionais dos Mbyá-Guarani vem de um mesmo padrão habitacional dos Tupi-Guarani antes da colonização. A figura 10 apresenta croquis esquemáticos do perfil construtivo da maloca dos Tupi-Guarani e da oga dos Mbyá-Guarani. 


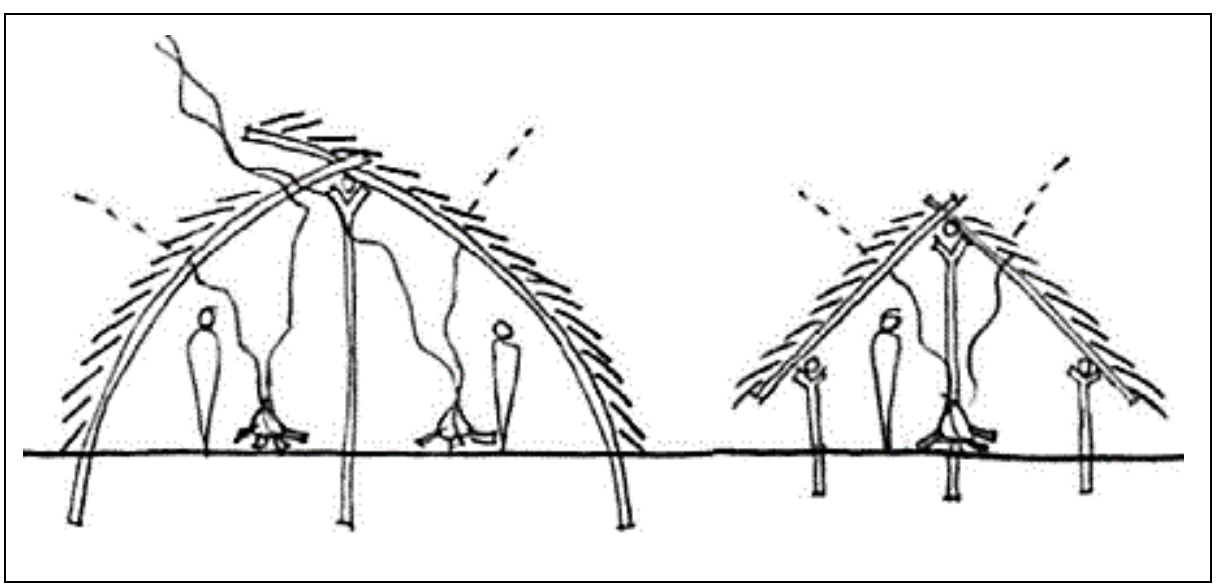

Figura 10: Maloca dos Tupi-Guarani e $O g a$ dos Mbyá-Guarani.

Para efeito de comparação, de acordo com Weimer (2005), as casas grandes dos Tupi-Guarani podiam chegar a 200 metros de comprimento por cerca de 12 metros de largura. Hoje, as casas tradicionais dos Mbyá-Guarani têm em torno de cinco metros de comprimento por quatro metros de largura. Além disso, esse autor explica que os materiais construtivos das casas grandes eram todos de origem vegetal, encontrados nos ambientes onde viviam. Segundo ele, o barro foi um material construtivo incorporado na cultura material indígena no Brasil após a colonização, tendo como origem a cultura construtiva africana. Assim, a tipologia arquitetônica da casa tradicional com uso do xaxim traz uma referência mais próxima àquela desenvolvida em um período précolonial por ser totalmente construída com fibras naturais, representando um resgate histórico da cultura construtiva indígena brasileira.

Segundo Simiema (2000: 228), “a casa deve ser vista como o resultado de relações socioculturais concretizadas em um determinado tempo". Nesse sentido, hoje, tanto a casa tradicional construída com xaxim ou com barro consiste na expressão física da cultura material e no resgate contemporâneo da memória viva dos Mbyá-Guarani no RS. Essas representam o resultado do momento histórico atual que estão vivendo, no qual buscam o desenvolvimento de estratégias próprias para a continuidade dos aspectos de sua cultura material. Eles vêm estimulando tanto discussões internas sobre a história construtiva desse povo, através da memória dos mais velhos, quanto discussões externas, a partir de espaço políticos e acadêmicos que reconhecem suas especificidades. As casas encontradas nos tekoá do RS representam a arquitetura contemporânea dos Mbyá-Guarani possível de ser materializada e desenvolvida. 
Apresenta-se a tipologia arquitetônica da casa de xaxim, desenvolvida por esse povo no Tekoá Nhüu Porã, a partir de aspectos gerais da tipologia propriamente dita, dos principais materiais construtivos, da descrição da tecnologia construtiva e seu processo construtivo.

\section{A tipologia arquitetônica da casa de xaxim}

A casa para os povos indígenas é percebida como um elemento vivo que tem seus ciclos de vida e de morte associados às necessidades de cada grupo. Segundo Rapoport (1972), a casa é considerada como um ente de extensão do próprio ser indígena e se caracteriza para além de uma estrutura física com função utilitária. $\mathrm{Na}$ realidade, a casa pertence ao contexto da comunidade, pois insere-se à trama dos aspectos simbólicos que determinam a expressão material de uma cultura. Como ressalva Costa (1989: 9), "não há povo sem cultura material, sem casas, ou pelo menos, ideias referentes ao espaço ou à habitação".

Para a descrição da tipologia arquitetônica da casa dos Mbyá-Guarani no Tekoá Nhüu Porã, buscou-se como referência alguns aspectos relevantes orientados por Baldus (1942), percussor de um roteiro para as primeiras incursões etnográficas sobre comunidades e arquitetura indígenas no Brasil. Segundo esse autor, a tipologia construtiva de uma casa deve ser definida por componentes físico-espaciais e socioculturais, associados à compreensão e às necessidades a cada grupo cultural, segundo sua cosmologia. Além disso, ele destaca que a tipologia construtiva está relacionada ao conjunto da complexidade de determinantes externos do ambiente e dos desejos internos humanos.

Considerando essas questões, apresenta-se aspectos gerais da tipologia da casa tradicional em cinco itens: (i) implantação e orientação solar; (ii) forma e proporções; (iii) espaços interno e externo; (iv) conforto ambiental; e (v) uso e durabilidade. Utilizou-se como referência as dimensões e características da casa do cacique, que permitiu a proximidade e o acesso ao espaço interno da casa ${ }^{10}$.

\footnotetext{
${ }^{10}$ A casa do cacique segue um mesmo padrão das demais casas do tekoá. Apenas a casa de reza é a que tem algumas diferenças de dimensões por ser uma casa que abriga mais pessoas. Porém, o acesso a essa casa não é permitido para não-indígenas, em nenhuma comunidade Mbyá-Guarani do RS.
} 


\section{a) Implantação e orientação solar}

Primeiramente, o aspecto fundamental para a implantação da casa, no contexto do tekoá, refere-se ao tipo de solo local, pois a casa deve estar em um local adequado para o plantio do milho sagrado (avaxi eteî). Esse alimento sagrado também influencia outros aspectos construtivos, todos voltados à sua melhor produção e armazenamento. Além disso, a questão da orientação solar é chave para a implantação da casa, pois o sol (Nhamandú) é a divindade cosmológica fundamental e deve alimentar a casa.

É através da porta da frente da casa, a única abertura existente, que a casa se relaciona diretamente com o sol. Essa porta deve estar posicionada para a orientação Oeste. Assim, a casa recebe o olhar de Nhamandú por trás, ao amanhecer (orientação Leste), iluminando a parede dos fundos, e, no final do dia, essa divindade entra na casa pela porta da frente (orientação Oeste). Para eles, são três as orientações solares, nas quais moram outras três divindades, além do sol: (i) Karaí a Leste, (ii) Tupã a Oeste) e (iii) Jakairá no zênite. Desta forma, o percurso do sol (Nhamandú), inicia pela morada de Karaí ao Leste, passando pela morada de Jakairá no zênite, e termina na morada de Tupã a Oeste.

Porém, nem todas as casas estão orientadas dessa forma. No caso do Tekoá Nhüu Porã, a porta da casa de reza está voltada para o Oeste e as demais casas estão para o Leste, assim como ocorre na maioria das casas de reza nos demais tekoá do Estado. Costa (1989) explica que, na realidade, qualquer casa pode ser uma casa de reza, pois é o chefe da família que possui o papel de liderança espiritual para com seu núcleo familiar. Dessa forma, quem decide sobre a posição da porta é o chefe da família. A figura 11 mostra as portas de duas casas no Tekoá Nhüu Porã, ambas orientadas para o Oeste. 




Figura 11: Porta de entrada da casa de xaxim.

Fotos: Vivian Ecker (2006) e Paulo de Fernandes (2003).

Cabe mencionar que a porta é denominada em Guarani de õkê, que também significa dormir, relacionando a função prioritária da casa como um local de descanso, pois a maioria das atividades ocorre do lado de fora. Além de localização, outros aspectos importantes são as suas dimensões, completamente diferenciadas do padrão convencional da casa não-indígena, que tem como parâmetro ser de no mínimo 2,10m de altura. A porta da casa dos Mbyá-Guarani deve ser estreita e baixa, com aproximadamente $1,60 \mathrm{~m}$ de altura $0,60 \mathrm{~m}$ de largura. Essas medidas podem estar associadas ao padrão de menor estatura desse povo, que é entre 1,4m e 1,8m. Mas, na realidade, a porta deve ter dimensões menores para que a pessoa entre abaixado, reverenciando e pedindo permissão para o acesso ao espaço interno da casa, gerando uma postura humilde e respeitosa.

\section{b) Forma e proporções}

A forma da casa tradicional consiste em uma casa com base retangular e cobertura de duas águas ${ }^{11}$. Considerando a casa do cacique (referência da pesquisa), as dimensões da base são pequenas, aproximadamente 3,5 x 4,0m (metros), a exemplo da casa, com área de $16 \mathrm{~m}^{2}$, formando uma planta retangular. Essas medidas, conforme Zanin (2006), são adequadas para abrigar famílias nucleares maiores ou menores, podendo variar de 4,0 x 6,0m $\left(24 \mathrm{~m}^{2}\right)$ a 3,0 x 4,0m $\left(12 \mathrm{~m}^{2}\right)$.

\footnotetext{
${ }^{11}$ Nos tekoá de São Paulo, a casa tradicional dos Mbyá-Guarani não tem a base retangular. A parte dos fundos da casa é arredondada.
} 
Em relação à inclinação do telhado, essa varia de acordo com as dimensões da base. No caso da casa de reza, que é uma casa maior para abrigar todos do tekoá, essa tem dimensões maiores que as demais casas de moradia, porém sua altura é a mesma das demais, o que torna a inclinação da cobertura menos acentuada. A figura 12 apresenta croquis das fachadas da casa de reza e da casa de moradia, exemplificando tais diferenças de inclinações.

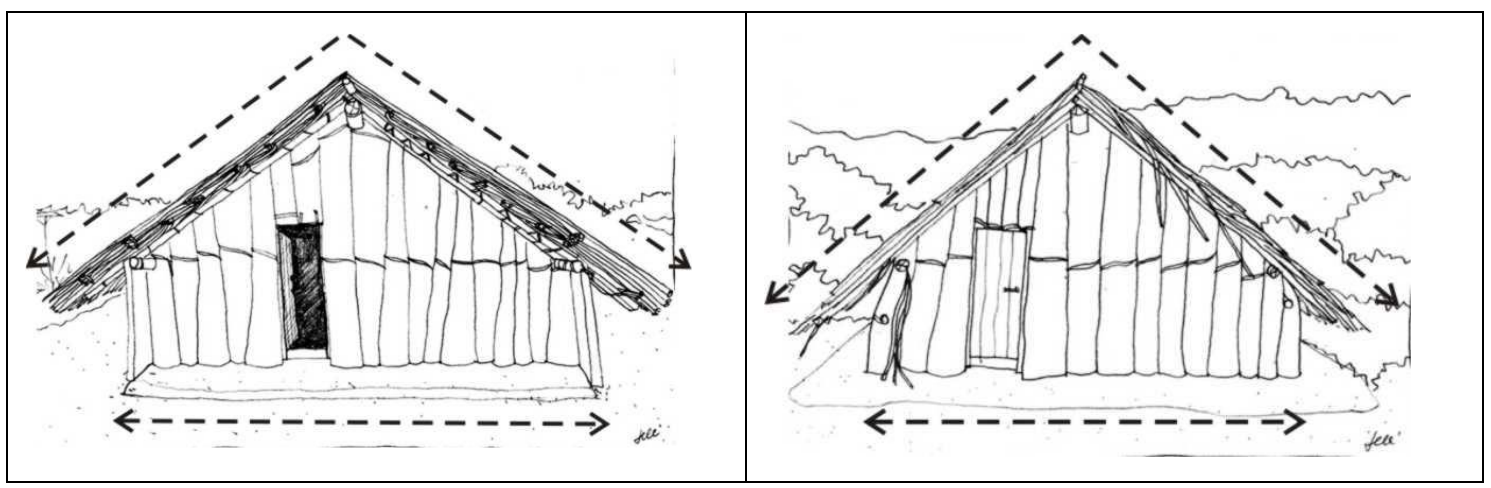

Figura 12: Inclinações da cobertura da casa de reza e da casa de moradia.

Como pode-se observar na figura acima, a cobertura de ambas as casas quase toca o solo e isso contribui para a proteção do material das paredes laterais (xaxim) e do material da cobertura (taquara batida), pois propicia o rápido escoamento da água da chuva. A altura das paredes laterais varia de 1,0 a 1,5m - mais baixa que a altura da porta. A altura no eixo central da casa é de $3,0 \mathrm{~m}$, propiciando, assim, uma inclinação acentuada, de aproximadamente 40\%. Segundo Lengen (2004), essa inclinação é adequada ao clima tropical úmido, chuvoso e quente, com muito vento e ampla variação térmica - características existentes nesse tekoá. A figura 13 apresenta a forma da casa e suas proporções, através de desenhos técnicos de planta baixa e corte transversal. 




Figura 13: Planta baixa e corte transversal da casa tradicional. 
$\mathrm{Na}$ figura acima, pode-se visualizar as dimensões da base, altura das paredes, inclinação da cobertura e a porta (única abertura), bem como algumas denominações dos elementos construtivos em Guarani - descritos posteriormente. Na planta baixa e no corte são mostradas, respectivamente, a projeção da cobertura no solo e sua inclinação acentuada. Além disso, pode-se visualizar como a distribuição interna dos poucos móveis existentes: (i) estruturas altas do solo que servem como camas (nhimbé), armários ou assentos; (ii) pequenos bancos (apiká); e (iii) o fogo (tatá) de chão. As técnicas construtivas e os materiais utilizados na estrutura, na parede e na cobertura também estão destacados na figura acima, correspondendo, respectivamente a: (i) cobertura de taquara mansa (takuá eteî); (ii) estrutura em cedro (ygaray) e taquara (takuá); (iii) amarração em cipó (yxypó); e (iv) parede de xaxim (xaxim).

\section{c) Espaços interno e externo}

O uso do espaço interno e do espaço externo da casa se diferencia pouco para os Mbyá-Guarani. Eles realizam as mesmas atividades tanto fora quanto dentro da casa. Internamente, a casa acaba tendo a função de abrigar do frio, dormir, guardar e cozinhar alguns alimentos, assim como reunir as pessoas em volta do fogo. Eles costumam usar com maior frequência o espaço externo, o pátio do entorno da casa. Esse pátio consiste em uma área coletiva que é dividida entre as casas de um mesmo núcleo familiar.

No espaço interno, no centro da casa, fica o fogo de chão, que é o principal mobiliário. Além de funções úteis, como servir para preparar alimentos, aquecer água, confeccionar artesanato e como iluminação noturna, o fogo tem significados fundamentais na cosmologia desse povo. Para eles, o fogo faz a proteção espiritual das pessoas e da própria casa e, por isso, deve permanecer sempre aceso, durante o dia e durante a noite, no inverno e no verão. Além disso, de acordo com Zanin (2006) e Felipim (2003), o fogo protege os materiais construtivos das casas e também as sementes do milho sagrado (avaxí eteí) que ficam penduradas na estrutura da cobertura recebendo fumaça. Na realidade, o calor do fogo propicia a redução da umidade do ar interno da casa e a fumaça impede o desenvolvimento de insetos e micro-organismos decompositores de matéria orgânica, tanto nos materiais construtivos quanto nas sementes de milho. 
A cor interna da casa é negra. A fumaça do fogo escurece a taquara batida da cobertura, a qual se torna escurecida. As paredes, por sua vez, são também escuras devido aos xaxins.

O piso interno, que corresponde ao próprio solo compactado, é o mesmo que o piso externo. Eles delimitam o pátio externo com o ato de varrer o solo todos os dias, fazendo com que fique compactado e diferenciado dos demais espaços externos à casa. A delimitação entre o piso interno e externo se dá através de uma valeta que fazem para a drenagem pluvial (água que desce da cobertura). A diferença entre ambos os pisos é que o piso interno é um pouco mais elevado.

Cabe ressaltar que esse tipo de piso (solo compactado) é fundamental para que seja possível existir o fogo de chão. Além disso, o contato direto com os pés na terra faz parte da cultura Mbyá-Guarani. Eles costumam andar descalços, tanto no inverno quanto no verão e isso é essencial para o seu modo de ser. O cacique do tekoá justifica que "as crianças não ficam com doença por estarem com os pés na terra" e o karaí acrescenta que eles "precisam caminhar descalços para crescerem fortes e tomarem contato com a Terra" (ASSECAN, 2007: 36).

Em relação ao espaço externo, eles constroem estruturas de madeira denominados yguaté, situando-as na parte da frente da casa (ver figura 13) ou em locais próximos. Esses armários servem como apoio para o resguardo de alimentos em relação aos animais. É no espaço externo onde fazem muitas atividades, como o preparo de alimentos, a produção de artesanato e a criação de pequenos animais, domésticos (gatos, cachorros e galinhas) e silvestres semidomesticados (quati, ratão-do-banhado e urubu) ${ }^{12}$. Além disso, costumam também usar o espaço externo para separar as sementes de milho colhidas em suas roças familiares, as quais são armazenadas dentro de casa posteriormente. A figura 14 mostra alguns dos usos do espaço externo à casa no Tekoá Nhüи Porã.

\footnotetext{
${ }^{12}$ De acordo com Freitas (2004: 99), é comum a domesticação dos animais silvestres como "animal companheiro" entre as famílias, os quais convivem soltos e próximos às casas de seus criadores.
} 


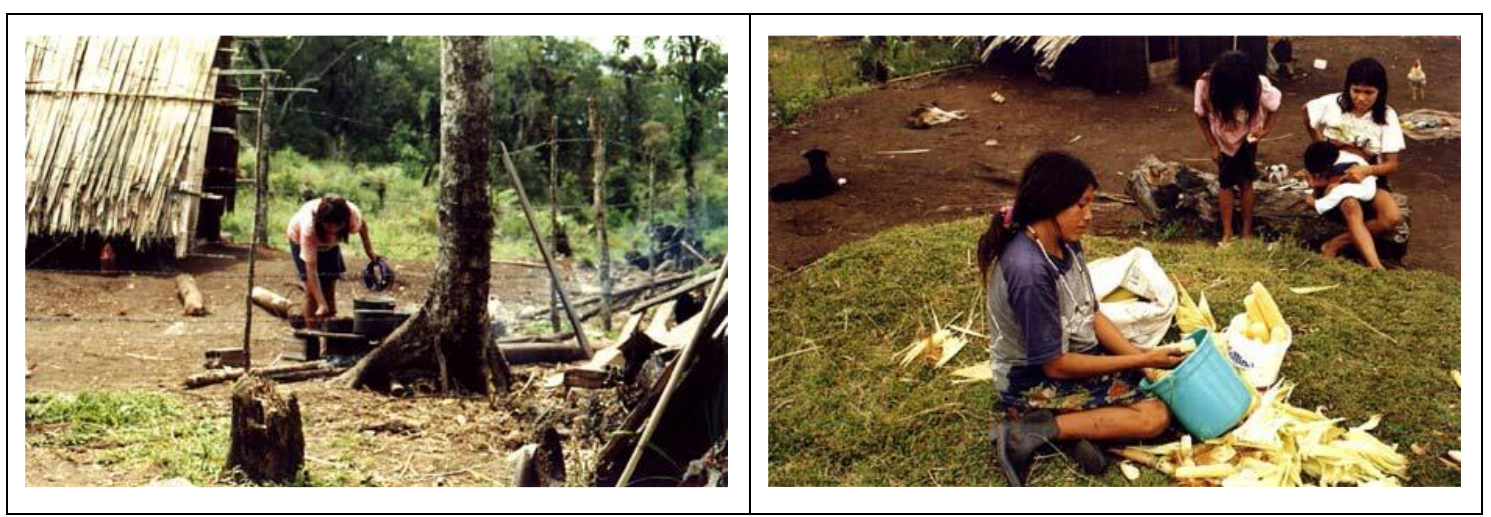

Figura 14: Espaço externo: preparação de alimentos e separação de sementes de milho.

Fotos: Paulo de Fernandes (2003).

Outra atividade fundamental da cultura Mbyá-Guarani que também ocorre normalmente na área externa da casa é o artesanato tradicional, como os cestos (adjaká) confeccionados pelas mulheres com tramas de taquara. As mulheres também fazem adornos, tais como colares, anéis e pulseiras com sementes, enquanto os homens confeccionam esculturas zoomórficas, em madeira tingida pelo fogo. Cabe mencionar que, através do artesanato, eles promovem as lembranças da sua história e de sua relação com a natureza, espíritos e deuses. Conforme Morinico et al (2007), as peças são realizadas através de rezas silenciosas que conectam o artesão com as divindades, pois, para cada espécie vegetal utilizada, eles pedem a autorização ao espírito da planta.

\section{d) Conforto ambiental}

$\mathrm{O}$ conforto ambiental da casa tradicional responde tanto às necessidades materiais e imateriais da cultura Mbyá-Guarani. Pode-se dizer que este conforto vem a ser a soma de padrões materiais e objetivos de conforto térmico, associados à iluminação e à ventilação, e padrões imateriais e subjetivos, associados à cultura do fogo e à proteção espiritual da casa e das pessoas.

A orientação solar da casa e a porta de entrada (única abertura), descritas anteriormente, auxiliam nesse conforto térmico. A porta direcionada para a posição Leste, ou para a posição Oeste, como ocorre em algumas casas, contribui para uma melhor orientação climática, pois ambas as posições fazem com que a cobertura tenha suas faces voltadas para as posições Norte e Sul. A face Norte da cobertura protege a casa da maior incidência solar, enquanto a face Sul dos ventos mais frios. Assim, a temperatura interna da casa se torna constante durante todo o ano. 
Além da orientação, o tipo de material e técnica construtiva também auxiliam para o conforto térmico. Devido às paredes serem de xaxim e ter uma espessura larga (cerca de $50 \mathrm{~cm}$ ), há uma maior inércia térmica, equilibrando as temperaturas dos ambientes interno e externo. A cobertura de taquara, em conjunto com a porta e o fogo de chão, propicia uma ventilação cruzada interna eficiente. Mesmo com uma única abertura, o ar entra pela porta, é aquecido pelo fogo e, por diferença de pressão, sobe em direção à cobertura, passando entre as frestas das taquaras. As fibras das taquaras batidas permitem a saída do ar, assim como da fumaça. Cabe mencionar que a tecnologia construtiva da cobertura faz com que o ar saia pelas fibras das taquaras, mas a água da chuva não entre. Isso se deve, principalmente, devido à inclinação acentuada da cobertura que permite um escoamento de água rápido e eficiente.

A iluminação natural interna da casa é outro aspecto importante do conforto ambiental, porém mais voltado aos aspectos imateriais e subjetivos. Consiste em uma iluminação baixa, em relação aos padrões não-indígenas, mas adequada às necessidades culturais dos Mbyá-Guarani, que precisam desse nível de iluminação. A iluminação ocorre basicamente pela porta de entrada da casa e indiretamente pelas frestas da cobertura de taquara. Dessa forma, a pouca iluminação natural associada à iluminação mínima do fogo de chão, bem como à cor escura dos materiais construtivos (paredes de xaxim marrom e cobertura de taquara escurecida pela fumaça), cria um ambiente propício para atenuar os sentidos perceptivos e não exacerbar o uso da visão, equilibrando melhor os sentidos perceptivos. Esse ambiente de penumbra é necessário para que eles possam entrar em contato com o mundo dos espíritos. Jecupé (1998: 21) destaca que a penumbra auxilia na relação comum entre o "mundo humano, suprahumano e divino" nas culturas indígenas.

\section{e) Uso e durabilidade}

O uso e a durabilidade da casa tradicional estão intimamente associados. O tempo de permanência de uma família em um mesmo local define o quanto deve durar a casa e isso determinada a qualidade dos materiais construtivos. A constante mobilidade dos Mbyá-Guarani, dentro ou fora dos tekoá, faz parte do seu modo de ser e, portanto, a casa será utilizada até o momento em que o deslocamento seja necessário. Dessa forma, 
algumas casas ficam sem uso por um determinado tempo, sendo reutilizadas posteriormente pela família que a construiu ou por outra que possa chegar ao tekoá.

Há também a possibilidade da casa não ser mais utilizada por motivos pessoais, como a morte de um parente. Assim, a casa deve voltar a se integrar ao ambiente natural e isso é possível pelo fato de ser construída com as espécies vegetais, as quais são decompostas, sem gerar resíduos.

Os materiais construtivos que servem de vedação lateral e cobertura, no caso, os xaxins nas paredes e as taquaras na cobertura, duram menos tempo que os materiais utilizados como estrutura. A estrutura é preferencialmente construída com espécies arbóreas de maior durabilidade, ao passo que os demais materiais acabam necessitando de um manejo mais frequente, com trocas ou reformas constantes.

Um aspecto-chave fundamental em relação à durabilidade da casa para os MbyáGuarani, que determina a sua permanência no tekoá, refere-se à cultivo e à produção do milho sagrado (avaxí ete). Eles usam os espaços de cultivo desse milho de forma rotativa, buscando aproveitar ao máximo as áreas próximas às casas. Dessa forma, o tipo de solo existente e as condições climáticas locais acabam determinando o aspecto temporal e cíclico da durabilidade da casa, e, por conseguinte, a qualidade dos materiais construtivos. Corroborando com Felipim (2001) e Costa (1993), quanto mais tempo eles preveem ficar em um determinado tekoá, maior será a qualidade do espaço de moradia. Quanto mais adequadas às características do ambiente (solo e clima) para o plantio do milho sagrado, melhor será a qualidade e o acabamento das casas. Assim, a durabilidade da casa é adequada aos períodos e ritmos em que esse povo dá aos deslocamentos.

\section{Materiais construtivos}

Os materiais construtivos da casa tradicional desenvolvida no Tekoá Nhüu Porã são todos recursos naturais típicos do Bioma Mata Atlântica, especialmente da Floresta Ombrófila Densa (Mata Atlântica, stricto senso). São espécies vegetais associadas a valores simbólicos e culturais dos Mbyá que deram preferência ao uso de algumas espécies por serem consideradas sagradas. A maioria são espécies que possuem características físicas adequadas à construção, tais como durabilidade e resistência. Mas, na perspectiva Mbyá, a escolha de tais espécies se deve por seus aspectos espirituais. 
Apresenta-se uma série de espécies vegetais utilizadas como materiais construtivos pelos Mbyá-Guarani, a partir da compilação de dados levantados em campo, em distintos tekoá do RS, e dados pesquisados pelos seguintes autores: Zanin (2006); Freitas (2004; 2006); Cadogan (2003); e Felipim (2003). Dentro do possível, apresenta-se o nome científico de cada espécie, assim como o seu nome em Guarani. Além disso, se especifica qual é a parte do vegetal utilizada (caule, colmo ou folhas); como se dá essa utilização, enquanto elemento construtivo (estrutura, parede, fechamento, cobertura ou amarração); e qual é o modo de aquisição (coleta, cultivo ou troca). O quadro 1 mostra 17 espécies utilizadas como materiais construtivos da casa tradicional. 


\begin{tabular}{|c|c|c|c|c|c|c|}
\hline $\mathbf{N}^{\mathbf{0}}$ & Nome popular & Nome científico & $\begin{array}{c}\text { Nome } \\
\text { Guarani }\end{array}$ & $\begin{array}{c}\text { Parte } \\
\text { utilizada }\end{array}$ & $\begin{array}{c}\text { Elemento } \\
\text { construtivo }\end{array}$ & $\begin{array}{l}\text { Modo de } \\
\text { aquisição }\end{array}$ \\
\hline 1 & Angico & $\begin{array}{l}\text { Parapiptadenia } \\
\text { rígida }\end{array}$ & Kurupá pitã & Caule & Estrutura & Coleta \\
\hline 2 & Bambu & $\begin{array}{l}\text { Guadua } \\
\text { angustifolius }\end{array}$ & Taquaruçú & Colmo & Parede & Coleta \\
\hline 3 & Camboatá & $\begin{array}{l}\text { Matayba } \\
\text { elaeagnoides }\end{array}$ & Yywata'y & Caule & Estrutura & Coleta \\
\hline 4 & Canela & Ocotea sp. & Yvyra ovi & Caule & Estrutura & Coleta \\
\hline 5 & Capim Santa-Fé & Panicum ivulare & Capi & Folhas & $\begin{array}{l}\text { Parede e } \\
\text { cobertura }\end{array}$ & $\begin{array}{l}\text { Coleta, } \\
\text { cultivo e } \\
\text { troca }\end{array}$ \\
\hline 6 & Cedro & Cedrela fissilis & Yary & Caule & $\begin{array}{l}\text { Estrutura / } \\
\text { fechamento }\end{array}$ & Coleta \\
\hline 7 & Cipó & -- & Yxypó eté & Caule & Amarração & Coleta \\
\hline 8 & Guabiju & $\begin{array}{l}\text { Myrcianthes } \\
\text { pungens }\end{array}$ & Yva viju & Caule & Estrutura & Coleta \\
\hline 9 & Guabiroba & $\begin{array}{l}\text { Campomanesia } \\
\text { xantocarpa }\end{array}$ & Guavira & Caule & Estrutura & Coleta \\
\hline 10 & Guajuvira & $\begin{array}{l}\text { Patagonula } \\
\text { americana }\end{array}$ & Gиајаиуиі & Caule & Estrutura & Coleta \\
\hline 11 & Guaimbé (cipó) & $\begin{array}{l}\text { Philodendron } \\
\text { bipinnatifidum }\end{array}$ & Wembe'pi & Caule & Amarração & Coleta \\
\hline 12 & Louro & $\begin{array}{l}\text { Cordia } \\
\text { trichotoma }\end{array}$ & Ajuy & Caule & Estrutura & Coleta \\
\hline 13 & Palmeira & $\begin{array}{l}\text { Arecastrum } \\
\text { romanzoffianum }\end{array}$ & Pindó eté & $\begin{array}{l}\text { Caule/ } \\
\text { folhas }\end{array}$ & $\begin{array}{l}\text { Parede/ } \\
\text { cobertura }\end{array}$ & $\begin{array}{l}\text { Coleta/ } \\
\text { cultivo }\end{array}$ \\
\hline 14 & $\begin{array}{l}\text { Pessegueiro- } \\
\text { bravo }\end{array}$ & Prunus sellowi & -- & Caule & Estrutura & Coleta \\
\hline 15 & Pitangueira & $\begin{array}{l}\text { Eugenia } \\
\text { uniflora }\end{array}$ & Anhangapiry & -- & Estrutura & Coleta \\
\hline 16 & Taquara-mansa & $\begin{array}{l}\text { Merostachys } \\
\text { clausenii }\end{array}$ & Takua ete $i$ & Colmo & $\begin{array}{l}\text { Cobertura/ } \\
\text { parede }\end{array}$ & Coleta \\
\hline 17 & $\begin{array}{l}\text { Samambaiaçu/ } \\
\text { Xaxim }\end{array}$ & $\begin{array}{l}\text { Dicksonia } \\
\text { selowiana }\end{array}$ & Xaxim & Caule & Parede & Coleta \\
\hline
\end{tabular}

Quadro 1: Espécies vegetais utilizadas como materiais construtivos.

Fonte: Prudente (2007).

Cabe mencionar que pode haver outras espécies vegetais utilizadas na construção pelos Mbyá-Guarani que não estão listadas nesse quadro. Algumas dessas espécies servem também para outros fins, como artesanato, medicina, xamanismo e alimentação, além da construção. Das 17 espécies listadas, averiguou-se o uso de algumas nas construções das casas tradicionais do Tekoá Nhüu Porã, das quais são descritas quatro espécies de maior relevância e preferência dessa comunidade no contexto desse trabalho, a partir de aspectos físicos e simbólicos: (i) cedro (6); (ii) samambaiaçu, ou xaxim (17), que é apenas utilizado nesse tekoá; (iii) taquara-mansa (16); e (iv) Guaimbé - cipó (11). 


\section{a) Cedro ou Yary (Cedrela fissilis)}

O cedro é a espécie arbórea preferida pelos Mbyá-Guarani para ser utilizada como elemento estrutural da casa, principalmente por ter uma importância na sua cosmologia. Além disso, é uma espécie que tem características físicas apropriadas à construção. A figura 15 mostra o uso do cedro como estrutura de pilares da casa e também como estrutura de vigas da cobertura.

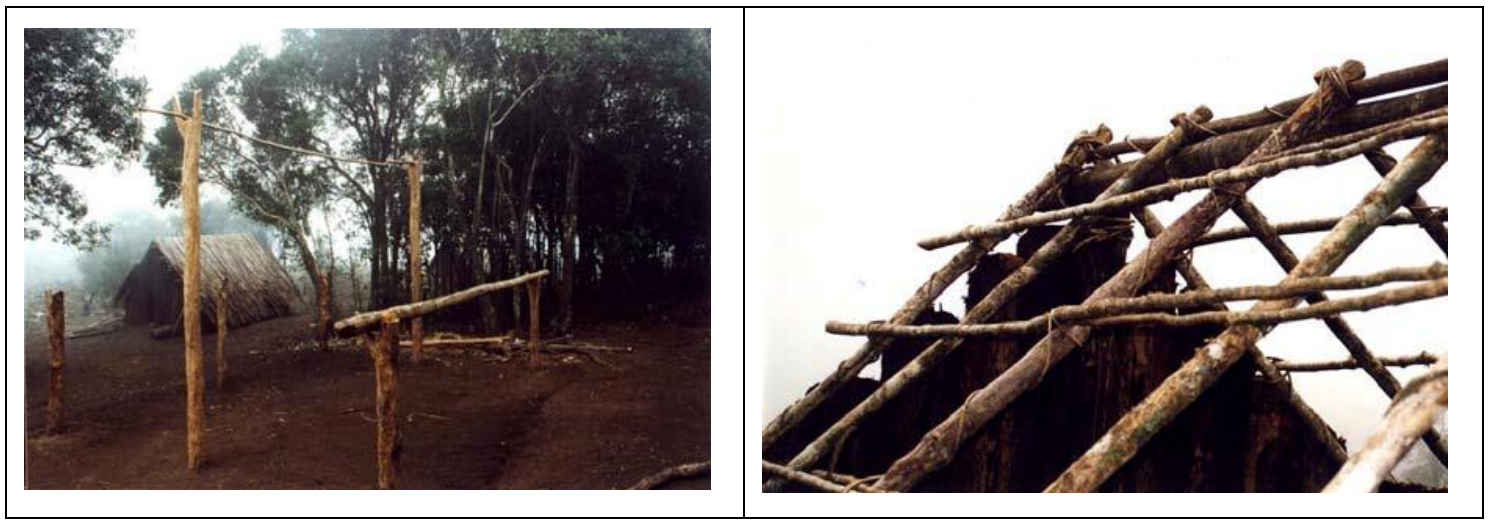

Figura 15: Cedro utilizado como estrutura de pilar da casa e vigas de cobertura. Fotos: Paulo de Fernandes (2003).

Para eles, o cedro relacionado aos mitos de criação e sustentação do mundo. Segundo Costa (1989), para os Guarani, o cedro foi uma das primeiras árvores criadas para apoiar e sustentar a abóbada celeste, o que remete ao poder de sustentação dessa espécie aplicada como estrutura da casa. Conforme Cadogan (2003), o cedro está associado a uma divindade chamada Yvyra Nhamandú, que corresponde à divindade do sol (Nhamandú). Para o karaí (líder espiritual) do Tekoá Nhüu Porãa, essa é uma espécie que possui muita energia de proteção e de cura (ASSECAN, 2007).

\section{b) Samambaiaçú ou xaxim (Dicksonia selowiana)}

O caule do xaxim é utilizado como vedação lateral das paredes das casas do Tekoá Nhüu Porã especificamente. Essa espécie vegetal foi associada a uma espécie de Palmeira, ou Pindó eté (13). Cabe mencionar que essa palmeira, o pindó para eles, é o material construtivo por excelência para ser utilizado nas casas tradicionais, pois tem um valor simbólico-cultural citado em quase todos os principais relatos mitológicos da cosmologia Guarani. Os Mbyá-Guarani utilizam o seu caule como material construtivo 
de vedação lateral (paredes) e suas folhas como material de cobertura. A figura 16 mostra o uso do xaxim como material de vedação lateral das paredes.

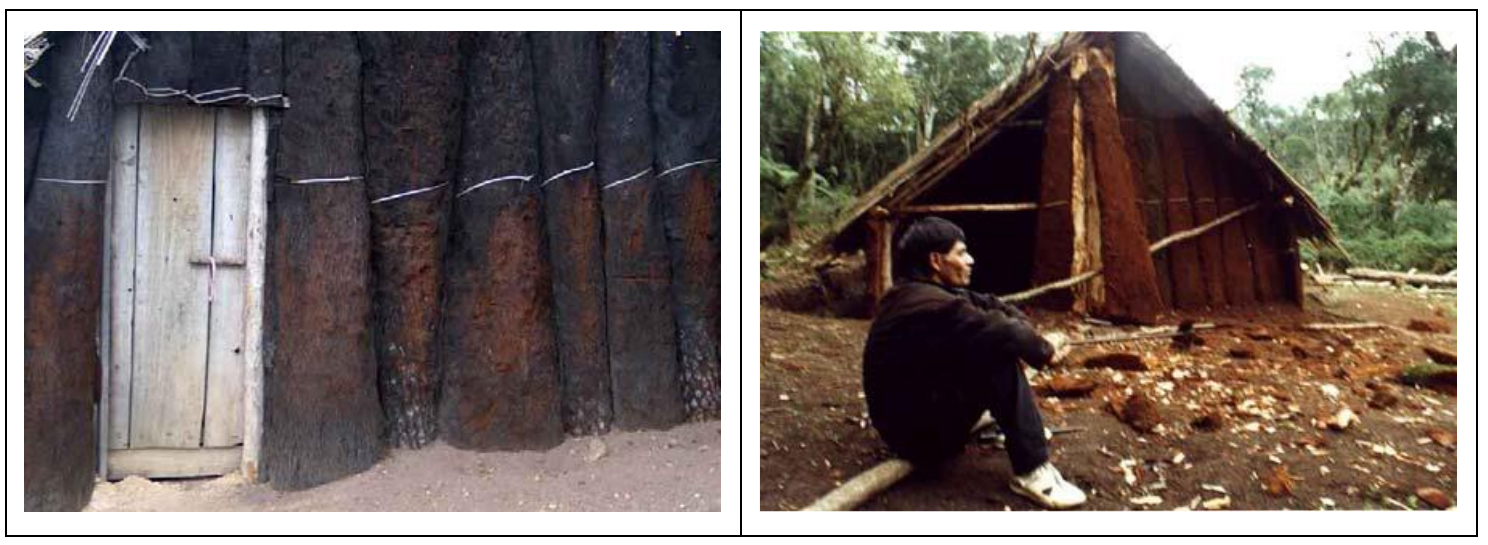

Figura 16: Xaxim como vedação lateral de paredes.

Fotos: Paulo de Fernandes (2003).

O histórico de utilização do xaxim nesse tekoá se deve justamente à associação com o pindó. O xaxim também é utilizado nas casas de tekoá da Argentina, mais especificamente na província de Missiones (região fronteiriça entre Brasil e Paraguai), de onde vieram algumas das famílias do Tekoá Nhüu Porã, como a família do cacique desse tekoá. Ele lembra era comum o uso do xaxim na construção de casas quando era pequeno e relata que, quando chegaram à Maquiné, observaram que havia pouco pindó e, por isso, pensavam que seria difícil construir da mesma forma que nos demais tekoá do RS. Por outro lado, eles perceberam que havia uma quantidade grande de xaxins e lembrou que, quando era pequeno, chegou a ajudar o seu avô a construir uma casa com essa espécie vegetal. Assim, decidiram usar o do xaxim como vedação lateral das casas.

Cabe registrar que o xaxim é considerado uma espécie em fase de extinção, legalmente proibida de ser coletada. Esse fato traz algumas controvérsias em relação ao seu uso pelos Mbyá-Guarani. Porém, eles o utilizam apenas para a construção de suas casas e não o comercializam, estando coerente com a legislação brasileira, através do Estatuto do Índio, que garante o uso exclusivo dos recursos naturais em terras indígenas, segundo seus costumes e tradições, desde que para o seu benefício e não para fins econômicos e comerciais (BRASIL, 1973). 


\section{c) Taquara-mansa ou Takua eteí (Merostachys clausenii)}

A taquara-mansa é uma das espécies de taquara utilizadas pelos Mbyá-Guarani como material construtivo para a cobertura das casas. Eles a denominam takua eteí, que significa "taquarinha verdadeira". Segundo Cadogan (2003), essa taquara está relacionada a um mito sobre uma heroína divinizada chamada Takuá Vera Chy Ete. O autor explica também que eles aproveitam para se alimentar de larvas comestíveis que se desenvolvem periodicamente nos taquarais secos dessa espécie. A taquara-mansa é também utilizada por eles para outros fins, além da construção, como a produção do artesanato e instrumentos musicais.

Na cobertura, os Mbyá-Guarani utilizam a taquara-mansa de duas formas na casa: como cobertura e como vedação lateral de paredes. Como cobertura, eles usam-na em forma de feixes macerados (amolecidos por batida), a partir de uma espessa camada. Como vedação lateral de paredes, eles a utilizam inteira ou em tramas e, nesse caso, acrescentam o barro normalmente como revestimento. Em relação às folhas de pindó, eles também preferem usar essa taquara por ela ter mais durabilidade, dependendo da execução e da espessura da camada da cobertura. A figura 17 mostra uma foto com o uso dessa espécie da taquara como material de cobertura.

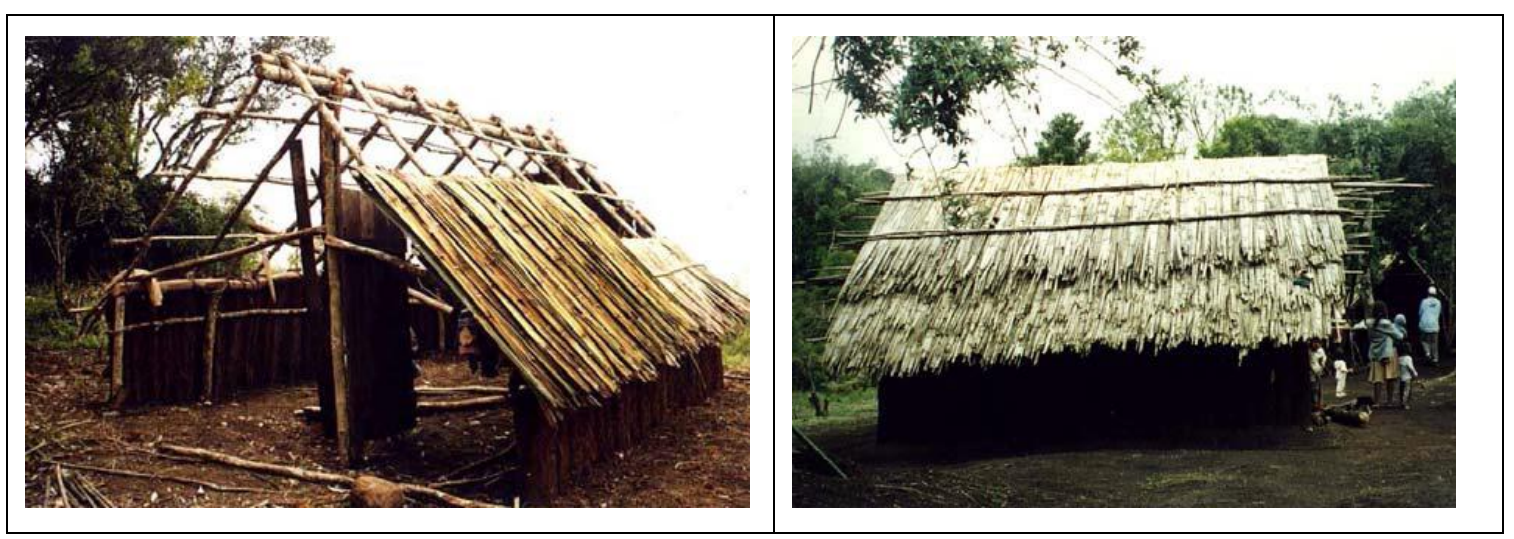

Figura 17: Taquara como cobertura e cipós como amarrações.

Fotos: Paulo de Fernandes (2003). 
Cabe mencionar que, em relação a outros materiais utilizados nas casas tradicionais na cobertura, como o capim (capí) ou as folhas de pindó (palmeira), eles consideram a taquara-mansa melhor. Em relação ao capim, para eles, a taquara-mansa é a mais tradicional, pois o capim veio a ser inserido na casa tradicional devido à influência da sociedade não-indígena, trazido pelos Guarani do Paraguai.

\section{d) Cipós ou yxypó}

Os cipós são fundamentais como materiais construtivos para os Mbyá-Guarani, pois têm a função de estabilizar a estrutura da casa, através de técnicas de encaixe e de amarração. Zanin (2006: 122) explica que o papel do cipó é ressaltado por eles através da expressão: “o cipó é nosso prego". Yxypó ${ }^{13}$ é uma etnocategoria que define uma gama de espécies de cipós nativos, os quais nem sempre tem correspondência na classificação botânica. Segundo Freitas (2004), além da construção, também são utilizados em outras atividades, como artesanato, medicina e alimentação. A autora destaca que algumas espécies têm preferência de uso e são referidas como yxypó ete, que significa "cipós verdadeiros", como o caso do cipó guaimbé ou wembépi em Guarani (Philodendron bipinnatifidum). A figura 18 mostra cipós coletado no Tekoá Nhüu Porã e utilizados no enlaçamento dos elementos que compõem a estrutura de vigas e pilares da casa.



Figura 18: Taquara como cobertura e cipós como amarrações.

Fotos: Paulo de Fernandes (2003)

\footnotetext{
${ }^{13}$ As espécies de cipós utilizados são identificadas e categorizadas pela etnia indígena, sendo uma gama de espécies que nem sempre tem correspondência na classificação botânica.
} 
Cabe destacar que há um grande cuidado dos Mbyá-Guarani em relação ao manejo dos cipós, assim como qualquer espécie vegetal que coletam nas matas. Freitas (2004) explica que, no caso dos cipós, esses são encontrados em maiores quantidades no contexto de ambientes alterados pelo homem, tais como interfaces de bordas de mata, capoeira e beira de estradas. A autora destaca que esse povo tem conhecimentos sobre as formas adequadas de coleta, pois priorizam espécies retas e maleáveis, com o corte feito próximo à altura do joelho para que se mantenha a raiz, permitindo, assim, que brotem novamente.

Cabe citar que nem todos os tekoá têm acesso às espécies preferenciais de cipó (yxypó eté), pois os cipós necessitam de outras plantas em áreas de mata para se apoiarem e crescerem em direção ao sol. Como nem todas as áreas indígenas têm áreas de mata com abundância de recursos naturais, não são todas as construções que utilizam os cipós. Nesse caso, ao invés de cipós, eles acabam buscando alternativas com outros materiais, como tiras de tecido, couro reciclados, pregos e arames comprados. Porém, nessas situações, eles relatam que pedem perdão a suas divindades por utilizarem elementos que não são tradicionais.

\section{Tecnologia construtiva}

A tecnologia construída da casa tradicional dos Mbyá-Guarani consiste em técnicas apropriadas aos ambientes naturais e sociais dos tekoá. Eles empregam basicamente os materiais construtivos citados anteriormente, os quais dialogam de forma integrada com as paisagens existentes por serem parte do próprio ambiente. Além disso, são técnicas que demandam processos coletivos durante a construção, reforçando os ritos sociais do sistema cultural desse povo.

No Tekoá Nhüu Porã, eles utilizam as mesmas técnicas construtivas que nos demais tekoá do RS, diferenciando-se apenas no uso da técnica para empregar o xaxim como material construtivo. Descreve-se cinco técnicas construtivas: (i) Estrutura de madeira (Oó itá); (ii) Cobertura de taquara batida (Takuá oje kava' ekue); (iii) Paredes de feto-a-pique (Oó korá); (iv) Amarração de cipó (Ojokuaá); e (v) Piso de chão batido (Yvyñapyroã). Essas técnicas foram elaboradas de forma a corresponder aos subsistemas construtivos, associados às espécies vegetais utilizadas. Além disso, buscou-se 
aproximar a técnica às denominações e significados que os Mbyá-Guarani fazem, relacionando-as aos alguns mitos de origem.

\section{a) Estrutura de madeira (Oó itá)}

Oó ita que significa "estrutura da casa como um todo", pois oó é casa em Guarani e itá é pedra, estrutura. Itá também está associada aos mitos de fundação do mundo para os Mbyá-Guarani. Conforme Costa (1993: 115), itá seria a pedra fundamental que sustenta a base da "segunda terra" (Avy Apy) - o mundo em que vivem hoje. Além disso, o autor explica que itá também remete a uma conotação de firmeza, estabilidade e base sólida da casa para eles. A palavra itá também está referida por eles, em relação à casa, na palavra ijytá, que significa a madeira, suporte, apoio ou pilar, usada como elemento construtivo estrutural. De acordo com Zanin (2006), ijytá é acrescida de algum sufixo que se referente à dimensão ou função da madeira como estrutura.

Dessa forma, pode-se descrever que a estrutura da casa, que consiste em um sistema estrutural independente de vigas e pilares em madeira, tem os pilares fixados no solo e estabilizados por vigas. Os pilares maiores são denominados itytá ete - estrutura verdadeira, ao passo que os pilares menores são denominados itytá mirí - estrutura menor. Os pilares maiores apoiam a viga de cumeeira (hakamby ete ru piguá), enquanto os pilares menores apoiam os frechais (hakamby ete ru piguá ou ijytá pukú). Esse sistema de pilares e vigas se estabiliza com as interligações dos demais elementos construtivos, tais como os caibros (ijytá î) e os travessões (ijytá î). Os caibros são apoiados e fixados na cumeeira (hakamby ete ru piguá) e nos frechais (ijytá uku), podendo receber entalhes e encaixes, sendo estabilizados com as amarrações de cipó. Os travessões, por sua vez, fazem o papel de vigas de suporte horizontal, instalados na face frontal e posterior da casa. Na face frontal, os travessões são adequados à altura da porta e, por vezes, cortados em dois. Além desses, há também as vigas de apoio que servem para amarrar os elementos que compõem as paredes, no caso os xaxins. A figura 19 mostra os cortes (lateral e longitudinal) e fachadas (frontal e lateral) da tipologia arquitetônica do Tekoá Nhüu Porã, destacando os nomes em Guarani dos sistemas e elementos estruturais. 


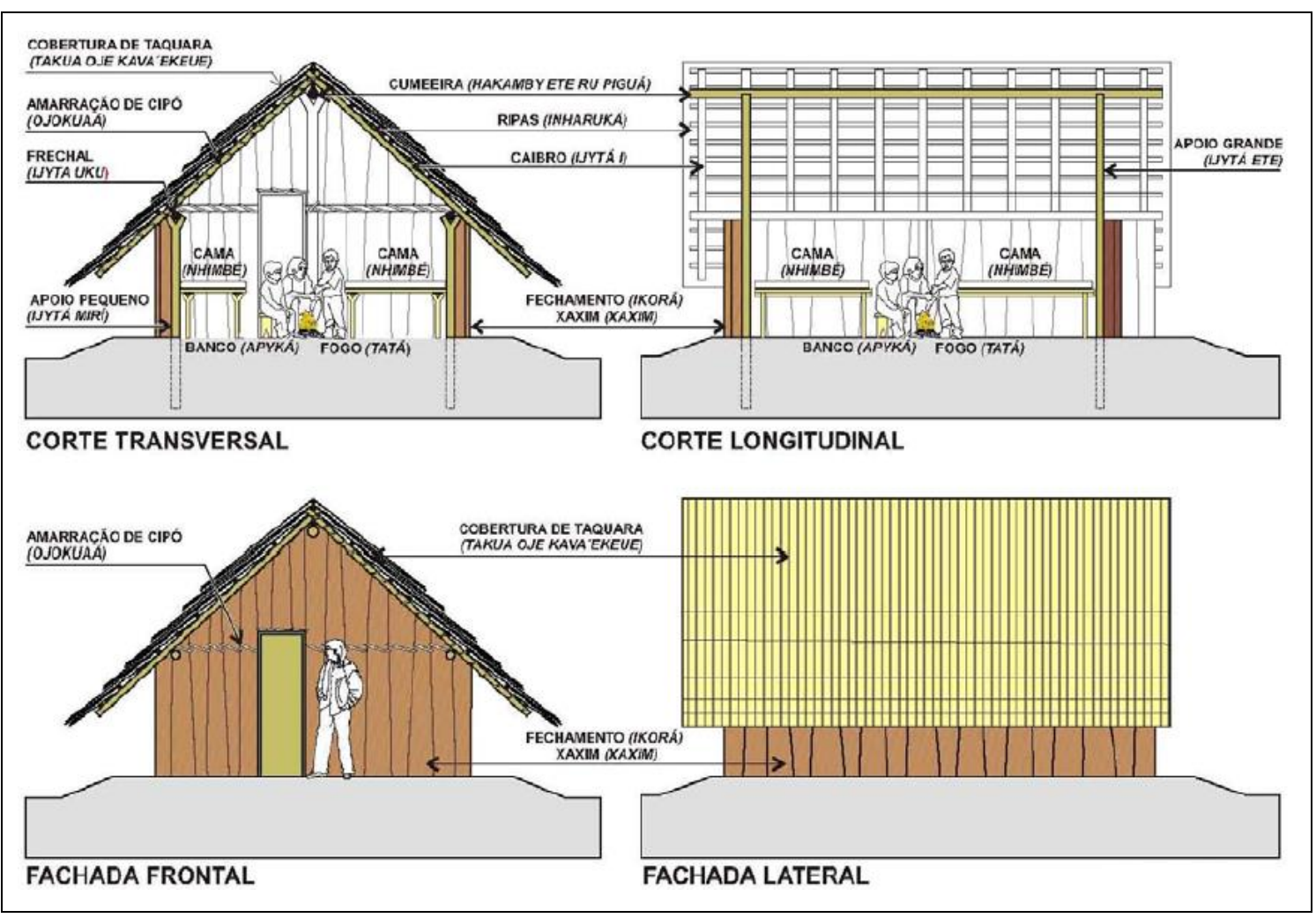

Figura 19: Cortes e Fachadas da tipologia arquitetônica.

A maioria dos elementos construtivos que compõem a estrutura da casa corresponde a espécies arbóreas em forma roliça, com diâmetros específicos, segundo a função desempenhada no sistema. Eles também utilizam espécies de taquaras como elementos que tenham funções secundárias, como travessões e vigas de apoio das paredes.

A estrutura da casa é o subsistema construtivo mais durável, o qual não necessita de reparos periódicos, diferentemente dos demais (paredes e coberturas). Pôde-se averiguar que as estruturas das casas no Tekoá Nhüu Porã estão em bom estado, mesmo as estruturas de pilares e vigas estejam expostas a intempéries. Algumas estruturas estão, no mínimo, há 10 anos sem paredes ou sem cobertura.

\section{b) Cobertura de taquara batida (Takuá oje kava'ekue)}

Essa cobertura é traduzida por eles como "telhas de taquara". A técnica de fixação da taquara à estrutura é basicamente a mesma dos demais materiais utilizados para esse fim, como o capim ou as folhas de pindó (palmeira), se diferenciando em alguns detalhes. Como a taquara-mansa é utilizada logo depois de colhida, ela é talhada 
ainda verde no sentido longitudinal para que se abra e, dessa forma, eles possam macerá-la facilmente com um pedaço de madeira. Zanin (2006) explica que esse processo propicia romper as fibras da taquara, transformando-os em feixes de taquara. As "telhas de taquara", na realidade, correspondem a diversos desses feixes.

As ripas da cobertura, que apoiam essas telhas, também são de taquara, porém de taquaras roliças cortadas ao meio (não macerada). Para tanto, os Mbyá-Guarani cortam as taquaras ao meio, no sentido longitudinal, e as denominam de takuá pengue, que significa "meia-taquara". Eles utilizam essa mesma forma de cortar a taquara para formar as telhas, pois dobram diversos feixes de taquara ao meio, encaixando-os e agrupando-os ao longo de uma meia-taquara dentro dessa dobra. Dessa forma, ocorre a montagem de uma das telhas de taquara.

Os feixes de taquaras (telhas) ficam dispostos, um ao lado do outro, formando um plano que é levado sobre as ripas de meia-taquara da cobertura. As ripas são colocadas sobre os caibros, com o corte voltado para dentro, facilitando o apoio sobre os mesmos. Depois, eles fazem as amarrações de cipó para fixar as taquaras ao conjunto da estrutura da cobertura. A colocação das telhas ocorre de baixo para cima, de um lado e do outro da cobertura, acabando com a colocação de uma última telha sobre a cumeeira (ijayte ru pinguá).

São empregadas diversas camadas sobrepostas de telhas de taquara (takuá oje kava' ekue) em ambos os lados da cobertura, buscando formar uma espessura adequada à necessidade de durabilidade. A cobertura deve formar uma camada que permita a saída de ar e fumaça de dentro da casa, mas não permitir a entrada da água da chuva. Ao final do processo, também costumam colocar outras taquaras horizontais sobre todas as telhas para a melhor fixação e amarração da cobertura como um todo. A figura 20 mostra um croqui esquemáticos das taquaras empregadas como elementos construtivos da cobertura. 


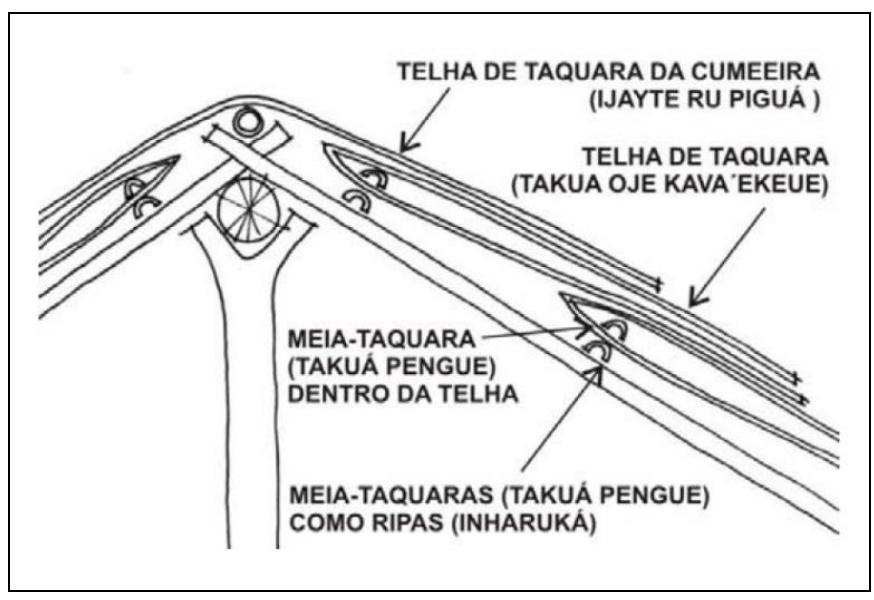

Figura 20: Telhas de taquara como cobertura.

Cabe ressaltar que, assim como técnica de usar a taquara batida como telha de cobertura, o uso do xaxim como paredes não há referências, sendo técnicas singulares desenvolvidas pelos Mbyá-Guarani no Brasil, específicas do Tekoá Nhüu Porã.

\section{c) Paredes de feto-a-pique (Oó korá)}

A denominação oó korá refere-se à parede da casa especificamente em Guarani e não à parede de xaxim propriamente dita. O termo oó korá pode se referir tanto à técnica de feto-a-pique quanto à de pau-a-pique, que normalmente é associada à técnica de taipa de mão (revestimento de barro). Não há um termo em Guarani específico à técnica de feto-a-pique, encontrada do Tekoá Nhüu Porã.

Diferentemente dos demais subsistemas construtivos, a técnica de paredes de feto-a-pique é exclusiva ao uso de uma espécie vegetal do xaxim como elemento de vedação de paredes. O termo "feto-a-pique" foi criado a partir da relação com a técnica construtiva de paredes denominada pau-a-pique, a qual é utilizada nos demais tekoá do RS. Conforme descreve Weimer (2005), essa técnica consiste em troncos ou galhos de madeira, razoavelmente retos, fincados ou apoiados no chão, fixados com um suporte horizontal na parte superior. O xaxim, por sua vez, consiste em um tronco caracterizado como uma massa fibrosa constituída de raízes entrelaçadas, classificado botanicamente, segundo Ferreira (2004), como "feto arborescente". Assim, por não uma madeira - ou um pau propriamente dito, denominou-se a técnica como feto-a-pique, a fim de associála ao xaxim especificamente. Nessa técnica, diferentemente do pau-a-pique, não há a necessidade de se acrescentar a técnica de taipa de mão, na qual utiliza-se o barro como 
revestimento $^{14}$. No pau-a-pique, são empregadas diversas madeiras roliças finas que seriam os paus, dispostos lado a lado no sentido vertical. Da mesma forma, são colocados os xaxins no feto-a-pique.

O feto-a-pique, portanto, consiste em troncos de xaxim dispostos na vertical, formando paredes largas de aproximadamente $25 \mathrm{~cm}$. Os xaxins são cortados ao meio, no sentido longitudinal, para otimizá-los e aproveitar melhor a largura dos troncos grossos - cerca de $50 \mathrm{~cm}$ de diâmetro. Os troncos cortados são dispostos ao meio no sentido vertical, um ao lado do outro, intercalados inversamente, para um melhor acabamento e vedação. Isso significa que um tronco fica com a parte mais larga para baixo e o próximo com a parte larga para cima. Assim, vão encaixando-os e apertandoos para que fiquem arranjados bem próximos. Isso é possível devido ao fato do xaxim se caracterizar como uma massa fibrosa constituída de raízes adventícias entrelaçadas, sendo extremamente maleável, permitindo comprimi-los sem que fique qualquer tipo de fresta. Desta forma, a vedação lateral da parede configura um bom isolamento sem necessidade de revestimentos, como no caso do barro. A figura 21 mostra um croqui esquemático de como são amarrados os xaxins na técnica de feto-a-pique.

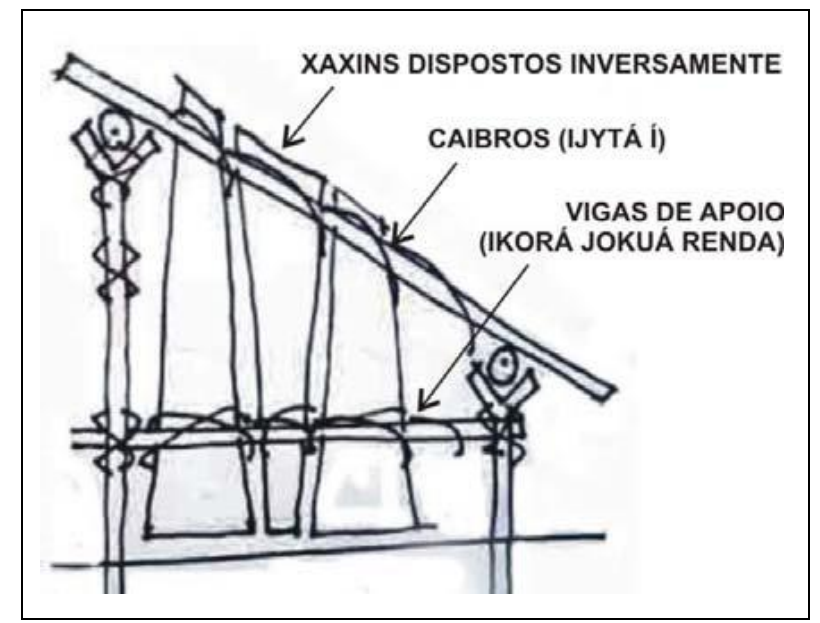

Figura 21: Técnica de feto-a-pique, com xaxins amarrados com cipós.

\footnotetext{
${ }^{14}$ Taipa de mão é uma das três denominações das técnicas associadas ao pau-a-pique, assim com a taipa de sebe ou de sopapo. Na taipa de mão, o barro serve para "fechar as frestas formadas entre os galhos verticais", sendo amassado com os pés, mãos ou meio, até que adquira devida consistência e posteriormente seja pressionado entre as frestas com a mão (Weimer, 2005: 262).
} 
A fixação dos xaxins ocorre através de enlaçamentos de cipó nos elementos estruturais da casa, como as vigas de apoio da parede (ikorá jokuá renda) e os caibros (ijytá $\hat{\imath}$ ) da cobertura. A face dos troncos de xaxim cortados ao meio no sentido longitudinal fica voltada para dentro da casa, deixando as paredes internas mais uniformes e as externas onduladas. Os troncos são apoiados diretamente no solo sem serem fincados, como seria normalmente no caso dos paus da técnica do pau-a-pique. Posteriormente, para otimizar a vedação na parte que fica em contato com o solo, eles colocam camadas de terra nas bases das paredes, tanto interna quanto externa da casa. Cabe registrar que, enquanto estão construindo as paredes das casas, os Mbyá-Guarani costumam distribuir os pedaços de xaxins que sobram da obra ao redor da casa e, assim, acabam brotando novamente e crescendo próximos às casas, como percebido em alguns núcleos familiares desse tekoá.

\section{d) Amarração de cipó (Ojokuaá)}

Essa técnica, denominada pelos Guaranis como Ojokuaá, é fundamental na construção das casas, pois consiste em amarrações de cipós que têm a função de estabilizar e fixar quase todos os elementos empregados na construção. O objetivo dessa técnica é interconectar todos os subsistemas construtivos.

A técnica de amarração na construção ocorre por encaixe e/ou enlaçamento. Nos elementos construtivos mais pesados, os quais são lascados até que criarem uma superfície de apoio, não há a necessidade de enlaçamento posterior. Já nas vigas de apoio dos pilares, as quais são apoiadas e estabilizadas pelo próprio peso nas forquilhas naturais, essas são posteriormente fixadas com o enlace de cipó. A amarração por encaixe e enlaçamento é mais empregada para uma melhor fixação dos elementos construtivos mais leves.

Os Mbyá-Guarani utilizam tanto a amarração por encaixe em conjunto com o enlaçamento com o uso do cipó. Mesmo nos elementos construtivos mais pesados, eles utilizam a amarração com enlaçamento de cipó, para garantirem a estabilidade e a durabilidade estrutural do sistema como um todo. Eles utilizam o cipó de forma contínua nas tramas e nos enlaçamentos dos elementos construtivos e, para isso, buscam selecionar e coletar etnoespécies de cipós específicas para serem usados na construção, ou seja, as referidas por eles como yxypó ete (cipó verdadeiro). São espécies que possuem características propícias, como resistência, flexibilidade e longo comprimento. 


\section{e) Piso de chão batido (Yvyñapyroã)}

Yvyñapyroã é a denominação que os Mbyá-Guarani usam tanto para se referirem ao piso interno e também ao piso externo. Um corresponde à extensão do outro, sendo ambos a mesma coisa para eles. Costa (1989: 281) explica que yvyñapyroã significa "o chão que nós pisamos" em Guarani.

A técnica de piso de chão batido consiste na compactação e limpeza do solo local, sem nenhuma pedra, folhas ou galhos. Os Mbyá-Guarani buscam os mesmos cuidados e manejo de seus pisos (internos e externos), compactando-os com um instrumento típico de sua cultura: a vassoura tradicional (typyxaú), utilizada diariamente para delimitar o espaço externo de seus núcleos familiares.

$\mathrm{O}$ piso externo costuma ser comum a mais de uma casa. Na área externa da casa, eles varrem o solo e o direcionam diretamente para paredes externas da casa, o que promove o aumento da eficiência da vedação na base das paredes. O piso interno é executado durante a construção da casa, a partir da terra que sai dos buracos de fundação. Essa terra é jogada para o espaço interior da casa e posteriormente é compactada. O piso interno fica a um nível mais alto que o piso externo. No caso das portas, onde não há vedações laterais (paredes), o piso interno é delimitado por um tronco horizontal ou uma tábua do mesmo material com que fazem a porta, o qual tem um papel de soleira.

As técnicas empregadas como tecnologia construtiva da casa tradicional dos Mbyá-Guarani no Tekoá Nhüu Porã se caracterizam pela criatividade no uso e no emprego das espécies vegetais selecionadas, assim como no uso do próprio solo local como elemento construtivo. Estas são soluções tecnológicas que primam pela simplicidade e pela adaptabilidade aos ambientes em eles que vivem, bem como aos recursos de que dispõem. Nesse sentido, corroborando com Weimer (2005), há uma postura desvinculada da arquitetura autóctone indígena em relação ao controle e ao domínio de conquistas tecnológicas contemporâneas, pois essas acabam delimitando materiais sofisticados que determinam e limitam formas construtivas, segundo o padrão da cultura industrial não-indígena. Diferentemente disso, o uso de materiais orgânicos, sem predefinições ou padrões dimensionais estanques, possibilita uma liberdade formal e diversas soluções apropriadas à cultura diferenciada dos Mbyá-Guarani, neste caso. 


\section{Processo construtivo - Potirõ}

O processo construtivo da casa tradicional dos Mbyá-Guarani se caracteriza por ser um processo coletivo, pois esse é o método de trabalho fundamental para todas as atividades que eles desenvolvem, conforme seu modo de ser. O termo potirõ é traduzido como "mutirão", o qual corresponde ao trabalho coletivo de ação mútua. Na perspectiva Mbyá-Guarani, potirõ está mais relacionado a um evento celebrativo de uma atividade específica do que a uma ação de trabalho para a sociedade não-indígena. Trabalhar em mutirão ou potirõ para eles compreende um ritual coletivo tradicional promovido para uma atividade que envolve um grupo de pessoas da mesma família.

No caso da construção, há um potirõ que reúne as pessoas da família que habitará a casa, juntamente com especialistas da construção Mbyá-Guarani que irão orientar o processo. Esse processo se dá centralizada na relação de parentesco, de acordo com a organização socioeconômica que é torno da família, podendo se estender a parentes que moram em outro tekoá, mas também a pessoas do próprio tekoá que queiram participar. As pessoas da família programam e convidam-nos para o potirõ a ser desenvolvido, providenciando alimentação para todos e alojamento para os que virão de outros locais, segundo suas relações tradicionais de reciprocidade. Nesse sentido, os potirõ são oportunidades de encontro e troca de informações entre pessoas, o que contribui para o fortalecimento tanto de suas redes de reciprocidade internas quanto e externas.

Durante o processo, todos contribuem: mulheres, homens, crianças e velhos. As mulheres são responsáveis pela produção alimentar e os homens pela obra. As crianças se envolvem como uma grande brincadeira, pois é assim que vão aprendendo as futuras atividades. Ao mesmo tempo, transmitem um sentimento de diversão que se percebe nos adultos e, inclusive, nas pessoas mais velhas que participam normalmente como orientadores do processo. Morinico e Wolf (2007) explica que, além desses, os MbyáGuarani também chamam suas divindades para acompanharem as obras e por isso trabalham com o coração, ficando felizes com o que fazem. Portanto, um potirõ de construção ou de outra atividade mais voltada a uma festa do que de a uma obrigação propriamente dita. 
Esse processo construtivo é apropriado ao meio socioambiental dos tekoá. Além de empregarem espécies vegetais do próprio local como materiais construtivos, entre outras questões ecológicas, as técnicas construtivas promovem ritos tradicionais de trabalho que incorporam atividades coletivas entre as pessoas. São atividades que incentivam a troca e a transmissão de conhecimentos, pois os responsáveis pela organização do processo são normalmente as lideranças paternas da família, as quais se somam às lideranças do tekoá (cacique e karaí). Além desses, há também os especialistas da área da construção que orientam o trabalho durante todas as etapas de obra. O processo construtivo coletivo dos Mbyá-Guarani é descrito a partir de dois aspectos: (i) especialistas em construção: o que sabe construtir (oó poá, ogapuá ou ogajapova'e) e o sabe tudo sobre a casa, ou o arquiteto (oga requa oi kua a pava'e); e (ii) etapas do processo construtivo (fundação, estrutura principal, fechamentos, montagem, piso e encerramento).

\section{a) Especialistas em construção}

Os Mbyá-Guarani possuem especialistas para cada assunto específico, de acordo com a atividade que irão desenvolver. Normalmente, os especialistas são pessoas de maior idade, com experiência para fazer o papel de orientar e ensinar os mais jovens, segundo seu sistema tradicional de aprendizagem por imitação. Na área da construção, há pessoas que sabem construir e outras que são especialistas propriamente ditos. As pessoas que sabem construir, como descreve Zanin (2006), são denominadas por eles através dos termos oó poá, ogapuá ou ogajapova'e. Além desses, também são denominados de forma diferente as pessoas que sabem tudo sobre a casa, cuja a tradução seria o arquiteto, através do termo oga requa oi kua a pava'e e. Portanto, dentre os especialistas em construção, são dois os papeis: os que sabem construir e os que sabem tudo sobre a casa.

Cabe mencionar que, de acordo com a perspectiva Mbyá-Guarani, a definição ou habilidade que cada um tem está associada ao que chamam de "dom". Esse, por sua vez, relaciona-se ao nome em Guarani que recebem quando criança no ritual do batismo tradicional chamado, o chamado Nhemongaraí. Durante esse ritual, conforme Ladeira e Matta (2004), a liderança religiosa (karaî) tem condições de saber qual é a divindade que acompanhará a pessoa durante sua vida e, dessa forma, passa um nome pessoal referente às qualidades e potenciais a serem desenvolvidas, chamadas de dom ou 
destino - caminho e aprendizado a ser percorrido. São poucos os nomes existentes em Guarani e quem recebem nomes masculinos de Verá e de Karai ${ }^{15}$ - filhos dos deuses Tupã e Karaí, respectivamente - são os mais apropriados à área da construção, entre outras habilidades. A partir desses das pessoas que têm esses dois nomes, criam-se grupos de trabalho para o potirõ da casa. Porém, nem toda a pessoa que é um oga requa oi kua a pava'e (arquiteto) possui um desses nomes, pois, nesse caso, o saber "tudo sobre a casa" remete a questões mais amplas também sobre a cultura.

No Tekoá Nhüu Porã, foram identificados dois especialistas da construção: o cacique e o karaí. O nome do cacique, nesse caso, não correspondia a um dos dois nomes acima citados e sim a Kuaray. Porém, ele é tanto um oga requa oi kua a pava'e (arquiteto) quanto um ogapuá (quem sabe construir), pois prima pela continuidade da construção das casas de xaxim por saber o quanto significa para a cultura MbyáGuarani. Além disso, o cacique também aprendeu a construir desde criança, trazendo ao Tekoá Nhüu Porã, inclusive, a tipologia arquitetônica da casa tradicional com o uso do xaxim. Já o karaí sim, seu nome era Verá e, além do seu dom de cura e de sabedoria sobre as ervas da comunidade, é também um ogapuá (quem sabe construir). Ambos orientaram a construção das casas nesse tekoá, assim como ambos são contra os processos de intervenções externas referentes às construções não-indígenas.

\section{b) Etapas do processo construtivo}

As etapas do processo construtivo da casa compreenderam duas partes: (i) as etapas prévias referentes à preparação do terreno (localização, marcação e limpeza do terreno) e dos materiais construtivos (coleta e tratamento); e (ii) as etapas referentes às técnicas construtivas descritas anteriormente (fundação, estrutura, cobertura, vedação lateral e piso). Todas as etapas são organizadas conforme os grupos que irão desenvolvê-las, sendo orientadas pelos especialistas da construção.

Nas etapas prévias, a primeira coisa que é a decisão sobre a localização da casa, a qual compete à futura família que busca escolher locais apropriados ao cultivo de suas roças, principalmente ao cultivo das sementes do milho sagrado (axaxí eté). Os locais ideais normalmente são as clareiras dentro das áreas de mata. Eles escolherem a área de moradia em conjunto com a área de roça. Depois da localização, eles prepararam o

\footnotetext{
${ }^{15}$ Karaí refere-se tanto a um nome próprio quanto a uma de suas divindades, assim como ao papel de liderança religiosa.
} 
terreno para ambas as áreas, deixando o espaço de casa subordinado ao espaço de roça. Assim, marcam local onde será construída a casa e a limpam-no para iniciar as obras. No posicionamento, eles deixam determinada a entrada da casa, deixando a porta orientada para a posição Leste ou Oeste.

Ainda nas etapas prévias, os Mbyá-Guarani preparam os materiais construtivos através da coleta e do tratamento das espécies vegetais que serão utilizadas. A coleta ocorre preferencialmente durante a lua minguante, pois é o período em que a seiva das plantas está concentrada nas raízes, evitando futuras rachaduras nas madeiras e deixando-a mais resistente ao ataque de insetos, cupins, fungos e outros. O tratamento é específico para cada espécie e para cada elemento construtivo. Zanin (2006) descreve que as espécies arbóreas são cortadas nas dimensões adequadas e usadas na forma roliça. Os pilares são lascados e recebem os entalhes necessários, se não precisarem de forquilhas. As taquaras são cortadas e levadas ao sol para que sequem antes de serem usadas.

Nas etapas das técnicas construtivas, o início das obras ocorre com a fundação. Eles locam as cavas que receberam os pilares. São seis cavas de aproximadamente um metro de profundidade, situadas paralelas no sentido longitudinal da casa. Uma parte da terra retirada das cavas é colocada no centro da casa e a outra parte retorna, posteriormente, às cavas de fundação para fixação dos pilares. Após a fundação, passam para a estrutura principal da casa, a qual compreende três grupos de pilares e vigas arquitravadas apoiadas nas forquilhas dos pilares.

A cumeeira é apoiada nos pilares centrais e os frechais nos pilares laterais. O peso desses elementos é suficiente para a estabilidade estática de da estrutura como um todo, sem que haja a necessidade da fixação com amarrações em cipó. Posteriormente são instalados os caibros que são apoiados em encaixes entalhados nas vigas e enlaçados com um mesmo cipó contínuo. Depois colocam os travessões verticais na face da frente e dos fundos da casa, adequando o espaço da porta na frente. As estruturas secundárias referem-se aos demais elementos construtivos auxiliares dos que compõe a cobertura e as vedações laterais, os quais são fixados com encaixes e enlaces de cipó. São instaladas as vigas de apoio das paredes à meia no sentido vertical para a fixação dos xaxins e, no caso da fachada frontal, são colocadas vigas de suporte para o acabamento do espaço da porta que servem como marco. Em seguida colocam sobre os caibros as ripas de meia-taquara para apoiar e fixar as telhas de taquara batida. 
Após a montagem da estrutura a casa, passam para os fechamentos horizontal (cobertura) e vertical (paredes). Um pode ocorrer antes ou depois do outro. Para a cobertura, as telhas de taquara são colocadas e fixadas com um mesmo cipó contínuo sobre as ripas, formando uma trama as telhas e as ripas - ambas de taquara. Essas telhas são dispostas de baixo para cima com larga sobreposição para terem uma espessura adequada, deixando que a última telha seja aberta sobre a cumeeira, a qual é fixada com uma taquara inteiriça interna. Ao final, amarram com cipós taquaras longas sobre as telhas, cobrindo todo o vão da cobertura, o que gera uma melhor fixação das telhas de taquara. Para as paredes, iniciam com a instalação dos troncos de xaxins cortados ao meio no sentido longitudinal da planta. Os troncos são dispostos verticalmente com as faces cortadas voltadas para o interior da casa e são apoiados diretamente no solo. Esses troncos são fixados com vigas de apoio, amarrados com enlaçamentos de cipós. Eles buscam formar uma trama entre um único cipó e os troncos de xaxins.

Por fim, preparam os pisos e fazem um encerramento do processo construtivo. Com o solo externo à casa, que consiste no piso externo, eles o varrem em direção à base das paredes da casa, a fim de vedar possíveis aberturas. Depois escavam uma drenagem pluvial ao redor do perímetro da casa, para o escoamento superficial da água do terreno. Para o piso interno, eles adicionam a terra retirada das cavas e ao solo existente dentro da casa, a fim de compacta-lo com pedaços de toras de madeira residuais dos elementos estruturais. O piso interno é mais elevado que o piso externo e as paredes de xaxim fazem o papel de contenção do solo compactado interno. O encerramento do processo se dá através de celebrações entre todos os envolvidos, por meio de rituais de início à nova morada. São comemorações coletivas com festas e rezas de agradecimentos às divindades que auxiliaram o processo. Há também momentos de celebrações dentro da casa para que todos os elementos construtivos empregados (espécies vegetais) somem energia e criem um único espírito, o espírito da casa nova, o qual deve ser alimentado diariamente com a presença do fogo no interior da nova morada.

O processo construtivo da casa tradicional dos Mbyá-Guarani, com as pessoas especializadas e as etapas do processo, demonstram a apropriação aos aspectos que englobam a reprodução de sua arquitetura culturalmente diferenciada, seja na localização, na coleta e manejo dos materiais específicos ou na montagem das etapas dos sistemas construtivos. 


\section{Considerações finais}

A arquitetura autóctone dos Mbyá-Guarani no RS, desenvolvida no Tekoá Nhüu Porã, é adequada ao modo de construir desse povo e contribui para a reprodução e continuidade do seu modo de ser. A tipologia arquitetônica da casa tradicional, com a especificidade de usar o xaxim como material construtivo, bem como os demais materiais, técnicas e processo construtivo, vem a ser apropriada à dinâmica de mobilidade tradicional desse povo, contribuindo com a memória e com o fortalecimento da rede de tekoá existente no Território Mbyá-Guarani nesse Estado. Destaca-se a coerência no uso de recursos existentes nos locais em que buscam viver, bem como a compatibilidade em relação à durabilidade da casa e às necessidades transitórias de espaço. Além disso, essa arquitetura promove dinâmicas de construção que se caracterizam por ritos coletivos cíclicos, os quais envolvem a comunidade local e as redes de parentescos externas, fortalecendo a organização sociocultural dos MbyáGuarani.

A cultura material expressa através dessa tipologia arquitetônica, culturalmente diferenciada dos Mbyá-Guarani, colabora para a construção e a reconstrução dos tekoá, pois incorpora as questões de transitorialidade e de imperfeição que são próprias do modo de ser desse povo. Esses aspectos devem ser compreendidos e respeitados pela sociedade não-indígena, porque confere uma arquitetura diferenciada que tem referência a uma cultura específica. De acordo com a cosmologia sistêmica desse povo, tanto os tekoá, como as casas, as roças ou a própria pessoa Mbyá-Guarani, estão conectados. Eles consideram que todos esses elementos podem expressar como é a cultura MbyáGuarani.

Portanto, esse trabalho buscou apresentar um pouco do registro da cultura construtiva autóctone existente no RS, a qual pode ser aprimorada e/ou utilizada como referência em futuros trabalhos realizados em comunidades indígenas, principalmente, nos tekoá dos Mbyá-Guarani. Cabe ressaltar a importância do resgate de aspectos históricos a partir da memória dos mais velhos, o que necessita um tempo maior de envolvimento e vivência junto às comunidades. Também são fundamentais o reconhecimento e a discussão com os técnicos indígenas (arquitetos) sobre como solucionar seus problemas de escassez de recursos naturais, a partir de questões de manejo ambiental e recuperação de suas áreas. Além disso, a inserção e a legitimação de 
Mbyá-Guarani nos processos de gestão de políticas públicas são chave para que sejam mais eficientes as intervenções externas em áreas indígenas. Para tanto, sugere-se dar mais atenção e escuta a esse povo com muita calma, paciência e principalmente respeito à sua sabedoria milenar.

\section{Referências}

ASSECAN (Associação Ecológica de Canela - Planalto das Araucárias). José Verá: MbiáGuarani. Projeto Mbiá-Guarani. Porto Alegre: ASSECAN, 2007.

BALDUS, H. Aldeia, casa, móveis e utensílios entre os Índios do Brasil: Sugestões para pesquisas etnográficas. São Paulo: Sociologia, 1942.

BRASIL. Lei $n^{o}$ 6.001, de 19 de abril de 1973. Dispõe sobre o Estatuto do Índio.

CADOGAN, L. Tradiciones Guaranies en el folklore paraguayo. Fragmentos de etnografia mbyá-guaraní. Assunção/ Paraguai: Fundacion Leon Cadogan, Centro de Estúdios Paraguayos Antônio Guash, 2003.

CEPI (Conselho Estadual dos Povos Indígenas). Mapa de localização das comunidades indígenas no Estado. Porto Alegre: SAA / CEPI, 2006.

COSTA, C. O Desenho Cultural da Arquitetura Guarani. Revista do Programa de Pósgraduação em Arquitetura e Urbanismo da FAUUSP, São Paulo, n.4, dezembro 1993.

Habitação Guarani: Tradição Construtiva e Mitologia. Tese de doutorado.

Faculdade de Arquitetura e Urbanismo. São Paulo: USP, 1989.

EMATER (Associação Riograndense de Empreendimentos de Assistência Técnica e Extensão Rural). Projeto de Assistência Técnica e Extensão Rural 2003/2004. Relatório Final de Avaliação - Convênio 025/03. Porto Alegre: MDA-SAF, EMATER/ RS, 2005.

FELIPIM, A. Guarani Mbyá: considerações sobre suas práticas agrícolas e manejo do ambiente. CTI (Centro de Trabalho Indigenista), 2003. Disponível em: <http://www.trabalhoindigenista.org.br>. Acesso em: 10 jul. 2005.

O Sistema Agrícola Guarani Mbyá e seus Cultivares de Milho: um estudo de caso na Aldeia Guarani da Ilha do Cardoso, município de Cananéia, SP. Dissertação de mestrado. Escola Superior de Agricultura Luiz de Queiroz. São Paulo: USP, 2001.

FREITAS, A. E de C.. Estudos Complementares ao EIA/ RIMA referentes ao componente indígena voltado ao processo de Licenciamento Ambiental do Sistema de reforço Eletroenergético à Ilha de Santa Catarina e Litoral Catarinense. ELETROSUL - Centrais Elétricas S.A. Porto Alegre: Neocorp, 2006.

. Tekoá Ka'aty - Grupo de Trabalho para Identificação e Delimitação da Terra Indígena Guarani Mato Preto, Rio Grande do Sul. Relatório Ambiental Circunstanciado. Porto Alegre: FUNAI, UNESCO, 2004.

JECUPÉ, K. A terra dos mil povos: história indígena brasileira contada por um índio. São Paulo: Petrópolis, 1998.

LADEIRA, M.; MATTA, P. Terras Guarani no Litoral: as matas que foram reveladas aos nossos antigos avós = Ka 'agüy Oreramói Kuéry Ojou Rive Vaekue Y. São Paulo: CTI, 2004.

LENGEN, J. Manual do Arquiteto Descalço. Porto Alegre: Livraria do Arquiteto, TIBÁ, 2004.

MORINICO, J.; WOLF, D. Cultura e Arte Indígena Guarani: Conhecendo um povo, valorizando uma cultura. Porto Alegre: IECAM, 2007.

MORINICO, J.; WOLF, D.; SCHROEDER, E. Artesanato Mbyá-Guarani. In: Exposição Cultura e Arte Indígena Guarani: conhecendo um povo, valorizando uma cultura [Palestra]. Porto Alegre: IECAM, MARGS, 2007.

PRUDENTE, L. T. Arquitetura Mbyá-Guarani na Mata Atlântica do Rio Grande do Sul: estudo de caso do Tekoá Nhüu Porã. Dissertação de mestrado. Pós-Graduação em Engenharia Civil. Porto Alegre: UFRGS, 2007.

RAPOPORT, A. Vivienda y Cultura. Barcelona: Editorial Gustavo Gili, 1972. 
SIMIEMA, J. Em que abrigos se alojam eles? In: Urí e Wãxí: Estudos Interdisciplinares dos Kaigang. Londrina: UEL, 2000.

SOARES, M. O fortalecimento do sistema cultural Guarani como estratégia de atuação do poder público. In: Reunião de Antropologia do Mercosul, VII, 2007, Porto Alegre [Anais]. Porto Alegre: UFRGS, 2007.

VIETTA, K. Mbyá: Guarani de Verdade. Dissertação de Mestrado. Pós-Graduação em Antropologia Social. Porto Alegre: UFRGS, 1992.

WEIMER, G. Arquitetura Popular Brasileira. São Paulo: Martins Fontes, 2005.

VIETTA, K. Mbyá: Guarani de Verdade. Dissertação de Mestrado. Pós-Graduação em Antropologia Social. Porto Alegre: UFRGS, 1992.

ZANIN, N. Abrigo na Natureza: Construção Mbyá-Guarani, Sustentabilidade e Intervenções Externas. Dissertação de mestrado. Pós-Graduação em Engenharia Civil. Porto Alegre: UFRGS, 2006.

Recebido em: 31/01/2017. Aprovado em: 06/04/2017. 